\title{
Anti-tumor effects of mevalonate pathway inhibition in ovarian cancer
}

Andy Göbel ${ }^{1,2^{*}+}$ DD, Valentina M. Zinna ${ }^{3+}$, Stefania Dell'Endice ${ }^{1}$, Nikolai Jaschke ${ }^{1,4,5}$, Jan Dominik Kuhlmann ${ }^{2,6,7}$, Pauline Wimberger ${ }^{2,6,7}$ and Tilman D. Rachner ${ }^{1,2,4}$

\begin{abstract}
Background: Ovarian cancer remains the most fatal gynecological malignancy. Current therapeutic options are limited due to late diagnosis in the majority of the cases, metastatic spread to the peritoneal cavity and the onset of chemo-resistance. Thus, novel therapeutic approaches are required. Statins and amino-bisphosphonates are inhibitors of the mevalonate pathway, which is a fundamental pathway of cellular metabolism, essential for cholesterol production and posttranslational protein farnesylation and geranylgeranylation. While this pathway has emerged as a promising treatment target in several human malignancies, its potential as a therapeutic approach in ovarian cancer is still not fully understood.
\end{abstract}

Methods: Human ovarian cancer cell lines (IGROV-1, A2780, A2780cis) were treated with increasing concentrations $(0.5-100 \mu \mathrm{M})$ of statins (simvastatin, atorvastatin, rosuvastatin) and zoledronic acid. Effects on cell vitality and apoptosis were assessed using Cell Titer Blue ${ }^{\oplus}$, Caspase $3 / 7 \mathrm{Gl}{ }^{\oplus}$, clonogenic assays as well as cleaved poly (ADPribose) polymerase (CPARP) detection. The inhibition of the mevalonate pathway was confirmed using Western Blot of unprenylated Ras and Rap1a proteins. Quantitative real-time PCR and ELISA were used to analyze modulations on several key regulators of ovarian cancer tumorigenesis.

Results: The treatment of IGROV-1 and A2780 cells with statins and zoledronic acid reduced vitality (by up to 80\%; $p<0.001)$ and induced apoptosis by up to 8 -folds $(p<0.001)$ in a dose-dependent fashion. Rescue experiments using farnesyl pyrophosphate or geranylgeranyl pyrophosphate evidenced that blocked geranylgeranylation is the major underlying mechanism of the pro-apoptotic effects. Gene expression of the tumor-promoting cytokines and mediators, such as transforming growth factor (TGF)- $\beta 1$, vascular endothelial growth factor (VEGF), interleukin (IL)-8, and IL-6 were significantly suppressed by statins and zoledronic acid by up to $90 \%$ ( $p<0.001)$. For all readouts, simvastatin was most potent of all agents used. Cisplatin-resistant A2780cis cells showed a relative resistance to statins and zoledronic acid. However, similar to the effects in A2780 cells, simvastatin and zoledronic acid significantly induced caspase 3/7 activation (6-folds; $p<0.001$ ).

(Continued on next page)

\footnotetext{
* Correspondence: Andy.Goebel@ukdd.de

${ }^{+}$Andy Göbel and Valentina M. Zinna contributed equally to this work.

${ }^{1}$ Division of Endocrinology, Diabetes, and Bone Diseases, Department of

Medicine III, Technische Universität, Fetscherstraße 74, 01307 Dresden,

Germany

${ }^{2}$ German Cancer Consortium (DKTK), Partner Site Dresden and German

Cancer Research Center (DKFZ), Heidelberg, Germany

Full list of author information is available at the end of the article
}

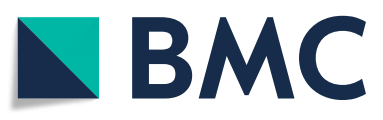

(C) The Author(s). 2020 Open Access This article is licensed under a Creative Commons Attribution 4.0 International License, which permits use, sharing, adaptation, distribution and reproduction in any medium or format, as long as you give appropriate credit to the original author(s) and the source, provide a link to the Creative Commons licence, and indicate if changes were made. The images or other third party material in this article are included in the article's Creative Commons licence, unless indicated otherwise in a credit line to the material. If material is not included in the article's Creative Commons licence and your intended use is not permitted by statutory regulation or exceeds the permitted use, you will need to obtain permission directly from the copyright holder. To view a copy of this licence, visit http://creativecommons.org/licenses/by/4.0/. The Creative Commons Public Domain Dedication waiver (http://creativecommons.org/publicdomain/zero/1.0/) applies to the data made available in this article, unless otherwise stated in a credit line to the data. 
(Continued from previous page)

Conclusion: Our in vitro findings point to promising anti-tumor effects of statins and zoledronic acid in ovarian cancer and warrant additional validation in preclinical and clinical settings.

Keywords: Ovarian cancer, Statins, Amino-bisphosphonates, Apoptosis, Mevalonate pathway

\section{Background}

Ovarian cancer is the leading cause of death from gynecological malignancies in women [1]. The survival rate of affected patients is comparably poor, especially due to the diagnosis at an advanced stage in the vast majority of the cases [2-4]. A consistent number of patients present few clinical symptoms, which are also characteristic of various gastrointestinal, abdominal and urinary conditions $[5,6]$. In many cases, the late diagnosis leads to a clinical picture that includes intraperitoneal dissemination of cancer cells [6]. Here, increased permeability of the peritoneal membrane and its associated vasculature leads to massive fluid accumulation (i.e. ascites) within the peritoneal cavity [7, 8]. This process is sustained and accelerated by inflammatory cytokines, chemokines and growth factors secreted by cancer cells and additional cellular components of the tumor microenvironment, such as lymphocytes and tumor-associated macrophages (TAMs) [4, 8, 9]. The resulting proinflammatory microenvironment supports the malignant invasive growth of the tumor and drives morbidity and mortality of affected patients [4]. Furthermore, ascites is associated with chemoresistance, recurrence, and an overall poor prognosis [4, 8]. Current therapeutic options in ovarian cancer management depend on the diagnosed stage and include radical cytoreductive surgery, which improves remission rates and results in a longer duration of tumor-free survival in over $90 \%$ of earlydiagnosed cases [10]. Adjuvant chemotherapy is more commonly administered in advanced ovarian cancer using carboplatinum and paclitaxel therapy which precedes and follows surgical cytoreduction [11, 12]. The anti-angiogenic drug bevacizumab was recently approved as an additional first-line therapy [13, 14]. Bevacizumab is administered in combination with the platinum-based chemotherapy and afterwards as maintenance monotherapy for a total of 15 months as used in the GOG0218 trial [13-15]). In addition, poly (ADP-ribose) polymerase (PARP) inhibitors have been approved in ovarian cancer [16]. Here, olaparib is approved as maintenance therapy after initial platinum-based chemotherapy for BRCA1/2 mutation carriers [17]. In so-called platinumsensitive ovarian cancer relapse PARP inhibitors are approved as maintenance therapy after response to platinumbased chemotherapy independent on the BRCA mutation status [18-21]. Major challenges in the management of ovarian malignancies are chemo-resistance to platinum- based therapy, metastases and disease recurrence [22]. Although patients with resistant tumors eventually respond to second-line therapies, a large proportion of them experience short disease-free survival [23]. Therefore, novel therapeutic options, especially for patients with chemo-resistant ovarian cancer, are urgently needed.

The mevalonate pathway is responsible for the biosynthesis of sterol and non-sterol isoprenoids, thereby playing a central role in cellular metabolism [24, 25]. Moreover, it is important for the post-translational modifications of proteins, specifically by providing farnesyl pyrophosphate (FPP) or geranylgeranyl pyrophosphate (GGPP) for farnesylation and geranylgeranylation, referred to as protein prenylation [26]. Due to their central role in regulating cellular signaling processes, RhoGTPases such as the Ras superfamily are among the best-studied prenylated proteins [27, 28]. The dysregulation and involvement of mevalonate pathway enzymes and products such as cholesterol in human malignancies has been shown for several tumor entities including ovarian cancer [25, 29-33]. Cholesterol can also be converted to 27-hydroxycholesterol by cytochrome $\mathrm{P} 450$ oxidase CYP27A1, which is expressed by both tumor cells and TAMs. CYP27A1 expression and 27-hydroxycholesterol promote tumor growth and are associated with reduced progression-free survival in breast and ovarian cancer [34, 35]. In addition, Rho-GTPases are implicated in ovarian cancer tumorigenesis and platinum resistance [36, 37]. Two major classes of drugs inhibit the mevalonate pathway at different levels: statins and amino-bisphosphonates (N-BP). Statins are inhibitors of the 3-hydroxy-3-methylglutaryl-CoA reductase (HMGCR), the rate-limiting enzyme of the mevalonate pathway. They reduce cholesterol production and mediate the increased uptake of extracellular cholesterol by low density lipoprotein receptors [38, 39]. Statins have evolved as a standard care for treating high cholesterol levels in patients $[39,40] . \mathrm{N}$ BP are inhibitors of the farnesyl diphosphate synthase and induce apoptosis in bone-resorbing osteoclasts [41, 42]. Therefore, N-BP are clinically used in osteoporosis or osteolytic bone metastases secondary to breast and prostate cancer $[41,42]$. Both classes of mevalonate pathway inhibitors show a multitude of pleiotropic antitumor effects, ranging from induction of apoptosis, inhibition of migration, metastasis and invasion, as well as modulation of tumorpromoting signaling molecules or the immune system [25, 43-46]. In this study, we aimed at investigating the in vitro 
anti-tumor effects of several statins and the N-BP zoledronic acid in different human ovarian cancer cell lines.

\section{Methods}

\section{Cancer cell lines and cell culture}

Human ovarian cancer cell lines A2780 and A2780cis were obtained from Sigma-Aldrich (Munich, Germany) in 2013 (catalogue numbers \# 93112519 and \#93112517). The IGROV-1 cell line was a kind gift of Dr. Jean Benard (Villejuif, France) in 2014. All cell lines have been authenticated by STR profiling at the DSMZ (Braunschweig, Germany) and tested for mycoplasma contamination by a standard PCR test. IGROV-1, A2780, and A2780cis were cultured in RPMI 1640 medium (Gibco ${ }^{\circ}$, Life Technologies, Darmstadt, Germany), supplemented with $10 \%$ fetal calf serum (FCS; Biochrom, Berlin, Germany) and 1\% penicillin/streptomycin (Biochrom, Berlin, Germany). IGROV-1 cells are cisplatin-sensitive cells, derived from a stage III ovarian carcinoma patient [47]. A2780cis cells were originally established as a cisplatin-resistant subclone of parental cisplatin-sensitive A2780 cells by chronic exposure to increasing cisplatin concentrations [48]. All cell lines were incubated in a humidified atmosphere at $37^{\circ} \mathrm{C}$ under $5 \% \mathrm{CO}_{2}$. To maintain chemo-resistance, A2780cis cells were supplemented with $1 \mu \mathrm{M}$ cisplatin every $2-3$ passages.

\section{Reagents and antibodies}

Cells were treated with simvastatin (SIM), rosuvastatin calcium (ROSU), atorvastatin calcium salt trihydrate (ATO), zoledronic acid (ZOL), farnesyl pyrophosphate (FPP), and/or geranylgeranyl pyrophosphate (GGPP). Stocks were prepared in dimethyl sulfoxide (DMSO), $\mathrm{dd}_{2} \mathrm{O}$ or were already delivered as solutions. All reagents were purchased from Sigma-Aldrich (Munich, Germany), except for ROSU (SelleckChem, Munich, Germany). Primary antibodies for Western Blot analyses were: anti-Rap1A (sc-1482; recognizes the ungeranylgeranylated Rap1a [49]), anti-Ras (\#610001) from BD Biosciences (Heidelberg, Germany), and anti-cleaved PARP (\#9541) from Cell Signaling Technology, Inc. (Beverly, MA, USA). For GAPDH, the anti-GAPDH (sc-25,778) from Santa Cruz (Heidelberg, Germany) and anti-GAPD H (\#5G4) from HyTest Ltd. (Turku, Finland) were used. Secondary horseradish peroxidase (HRP)-conjugated antibodies were anti-rabbit IgG (HAF008), anti-mouse IgG (HAF007), and anti-goat IgG (HAF109) from R\&D Systems, Inc. (Minneapolis, MN, USA).

Vitality, apoptosis, and clonogenic assays of cancer cells Cell viability was assessed using the CellTiterBlue ${ }^{\bullet}$ assay (Promega, Mannheim, Germany) according to the manufacturer's protocol. A Caspase $3 / 7 \mathrm{Glo}^{\circ}$ assay (Promega) and the detection of the cleaved fragment of poly (ADP- ribose) polymerase (PARP) were performed to detect apoptosis. Caspase 3/7 $\mathrm{Glo}^{\circ}$ and CellTiterBlue measurements were completed using the FluoStar Omega (BMG labtech, Jena, Germany). For the clonogenic assay [50], 200 vital IGROV-1 cells were seeded in each cavity of 6well plates and treated with statins and zoledronic acid, according to the indicated concentrations. Plates were incubated at $37{ }^{\circ} \mathrm{C}$ and $5 \% \mathrm{CO}_{2}$ for 9-10 days, until a sufficient number of colonies was reached, but before individual colonies started to fuse. A colony was defined as containing at least 50 cells. Colonies were washed with PBS, fixed with $10 \%$ paraformaldehyde for $30 \mathrm{~min}$ and stained with $0.02 \%$ crystal violet in $2 \%$ ethanol at room temperature (RT) for $15 \mathrm{~min}$. Plates were washed with tap water and dried at RT. Elution of the crystal violet staining was done with $10 \%$ SDS and absorbance was measured at $595 \mathrm{~nm}$.

RNA isolation, reverse transcription, and quantitative realtime polymerase chain reaction (qRT-PCR)

The analysis of gene expression was performed as previously described [51]. RNA isolation was performed using the High Pure RNA Isolation Kit (Roche; Mannheim, Germany), according to the manufacturer's protocol. RNA samples were quantified using Nanodrop (ND1000, Thermo Fisher Scientific, Erlangen, Germany). Reverse transcription of 500 ng RNA was performed using SuperScript II reverse transcriptase and RNaseOUT ${ }^{\mathrm{Tm}} \mathrm{Re}$ combinant Ribonuclease inhibitor (all from Invitrogen, Karlsruhe, Germany). The cDNA samples were analyzed for gene expression by qRT-PCR, using a Power SYBR ${ }^{\circ}$ green-based PCR MasterMix (Applied Biosystems, Darmstadt, Germany), according to a standard protocol with the 7500 Fast Real-Time PCR System (Applied Biosystems, Carlsbad, CA, USA). The primer sequences (Sigma-Aldrich, Hamburg, Germany) that were used are listed in Table 1. The results were examined using the $\triangle \triangle C T$ method and are shown as changes of gene expression relative to the GAPDH housekeeping gene.

\section{Immunoblotting}

Western blot analyses were performed as previously described [52]. Total protein was isolated from treated cells by using a sodium dodecyl sulfate (SDS)-based lysis buffer $(20 \mathrm{mM}$ Tris/ $\mathrm{HCl} \mathrm{pH} 7.4 ; 1 \%$ SDS; protease inhibitor cocktail (Roche)). Ten to $20 \mu \mathrm{g}$ of protein were loaded on a $10-12 \%$ SDS polyacrylamide gel electrophoresis (SDS-PAGE). Proteins were blotted on nitrocellulose membranes $(0.2 \mu \mathrm{m})$ and blocked using $5 \%$ bovine serum albumin (BSA) or $5 \%$ nonfat dry milk in Trisbuffered saline with 1\% Tween-20 (TBS-T) at RT for at least $1 \mathrm{~h}$. After washing in $1 \mathrm{x}$ TBS-T, membranes were incubated with primary antibody in blocking buffer at $4{ }^{\circ} \mathrm{C}$ overnight. Subsequently, membranes were washed 
Table 1 Primers used in the study

\begin{tabular}{|c|c|}
\hline Genes & Sequences $\left(5^{\prime}-3^{\prime}\right)$ \\
\hline$B C L-2$ & $\begin{array}{l}\text { F: TGTGTGTGGAGAGCGTCAAC } \\
\text { R: GACAGCCAGGAGAAATCAAAC }\end{array}$ \\
\hline GAPDH & $\begin{array}{l}\text { F: AGCCACATCGCTCAGACAC } \\
\text { R: GCCCAATACGACCAAATCC }\end{array}$ \\
\hline IL6 & $\begin{array}{l}\text { F: TACCCCCAGGAGAAGATTCC } \\
\text { R: TITTCTGCCAGTGCCTCTIT }\end{array}$ \\
\hline IL-8 & $\begin{array}{l}\text { F: CTGGACCCCAAGGAAAACTG } \\
\text { R: TTCTCAGCCCTCTTCAAAAAC }\end{array}$ \\
\hline$S V V$ & $\begin{array}{l}\text { F: GAACTGGCCCTTCTTGGAG } \\
\text { R: AAGTCTGGCTCGTTCTCAGTG }\end{array}$ \\
\hline$T G F \beta 1$ & $\begin{array}{l}\text { F: TGCTAATGGTGGAAACCCACAACG } \\
\text { R: TCTCGGAGCTCTGATGTGTTGAAG }\end{array}$ \\
\hline TNFA & $\begin{array}{l}\text { F: CTCCTCACCCACACCATCAG } \\
\text { R: GGAAGACCCCTCCCAGATAG }\end{array}$ \\
\hline VEGF & $\begin{array}{l}\text { F: GTGATGATTCTGCCCTCCTC } \\
\text { R: CCTTGCTGCTCTACCTCCAC }\end{array}$ \\
\hline
\end{tabular}

$B C L-2$ B-cell lymphoma 2, GAPDH glyceraldehyde 3-phosphate dehydrogenase, IL6 interleukin 6, IL8 interleukin 8, SVV survivin, TGF $\beta 1$ transforming growth factor $\beta 1$, TNFA tumor necrosis factor a, VEGF vascular endothelial growth factor

in $1 \mathrm{x}$ TBS-T and incubated with HRP-conjugated secondary antibodies at RT for $1 \mathrm{~h}$. The luminescent ECL detection kit (Pierce, Thermo Fisher Scientific, Schwerte, Germany) was used for visualization of the proteins. Chemiluminescence was detected using MF-ChemiBIs 3.2 imager (Bio-Imaging Systems, Germany) and GelCapture 7.0.18 software (DNR Bio-Imaging System Ltd.). Original blots were cropped for the arrangement of the final figures and are included in the supplementary (Suppl. Figs. 5, 6, 7, 8).

\section{Enzyme-linked immunosorbent assay (ELISA)}

A human IL-6 ELISA kit (Peprotech, Hamburg, Germany) was used to assess the secreted levels of IL-6 in the supernatants of IGROV-1 cells. Briefly, 96-well ELISA plates (biomat srl, Rovereto, Italy) were coated with capture antibody $(1 \mu \mathrm{g} / \mathrm{ml})$ against IL-6 and incubated overnight at $4{ }^{\circ} \mathrm{C}$. Wells were washed $(0.05 \%$ Tween-20 in PBS) and blocked with 1\% BSA in PBS. After washing, ELISA plates were coated with supernatants of IGROV-1 cells (1:20 in $0.05 \%$ Tween-20 and $0.1 \%$ BSA in PBS) and incubated for $1 \mathrm{~h}$ at RT. To detect cytokines bound to the capture antibody, ELISA plates were washed again and subsequently coated with a detection antibody $(0.25 \mu \mathrm{g} / \mathrm{ml})$ and Avidin-HRP-conjugate (1:2000). The color development after adding ABTS substrate (Sigma-Aldrich, Hamburg, Germany) was detected using the FluoStar Omega (BMG labtech) at $405 \mathrm{~nm}$, with wavelength corrected at $650 \mathrm{~nm}$.

\section{Statistical analyses and software}

Results are presented as means \pm standard error of the mean (SEM), from experiments in technical duplicates repeated at least three times with biological replicates. Outliers were determined via Grubb's test. Group analyses were performed using one-way analysis of variance (ANOVA) by GraphPad Prism 6.07 (GraphPad, La Jolla, CA, USA). For direct comparisons between A2780 and A2780cis cells, a two-way ANOVA with a Bonferroni post-test was performed. $P$-values $<0.05$ were considered statistically significant.

\section{Results}

Statins and zoledronic acid inhibit the mevalonate pathway and suppress vitality in IGROV-1 and A2780 cells IGROV-1 and A2780 ovarian cancer cell lines were treated with increasing concentrations of atorvastatin, simvastatin, rosuvastatin, or zoledronic acid. IGROV-1 cells were treated for $48 \mathrm{~h}$ while A2780 cells were treated for $24 \mathrm{~h}$ due to a higher sensitivity. The effective inhibition of the mevalonate pathway was verified by the accumulation of ungeranylgeranylated Rap1a and unfarnesylated Ras (Fig. 1a). While unprenylated Rap1a appeared upon treatments as a single band, unprenylated Ras was distinguishable by a second smaller band above the prenylated protein. At a concentration of $1 \mu \mathrm{M}$, atorvastatin and simvastatin were already sufficient to block the mevalonate pathway, indicated by a strong accumulation of ungeranylgeranylated Rap1a (Fig. 1a). The vitality of IGROV-1 cells was reduced in a dose-dependent fashion with a maximal loss of $60 \%$ at a concentration of $25 \mu \mathrm{M}$ simvastatin/atorvastatin (Fig. 1b; $p<0.001)$. IGROV-1 cells were insensitive to $1-10 \mu \mathrm{M}$ rosuvastatin/zoledronic acid, but a significant loss of vitality was achieved by $25-100 \mu \mathrm{M}$ (Fig. $1 \mathrm{~b} ; p<0.001$ ). Interestingly, the clonogenic potential of IGROV-1 cells was already significantly suppressed by $0.5 \mu \mathrm{M}$ simvastatin ($55 \%$ number of colonies; Suppl. Fig. 1 ; $p<0.001)$. Compared to IGROV-1, A2780 cells responded with a higher sensitivity to any of the substances, with a reduction of cell vitality by up to $80 \%$ using the highest concentrations after $48 \mathrm{~h}$ (Fig. 1b; $p<0.001$ ). In both cell lines, simvastatin was the most potent of the used statins, with a significant reduction of cell vitality at $2.5 \mu \mathrm{M}(p<0.001)$.

\section{Inhibition of the mevalonate pathway induces apoptosis in IGROV-1 and A2780 cells}

Next, we assessed activation of caspases 3 and 7 after treatment of IGROV-1 and A2780 cells for $48 \mathrm{~h}$ with the same concentrations of statins and zoledronic acid. A significant induction of caspases $3 / 7$ activity, by up to 6folds and up to 8-folds, was observed with increasing concentrations of any statin and zoledronic acid in A2780 and IGROV-1, respectively (Fig. 2a; $p<0.001$ ). Again, A2780 cells appeared to be more sensitive to statins compared to IGROV-1 cells as a significant activation of caspases $3 / 7$ was obtained using $1 \mu \mathrm{M}$ simvastatin or $10 \mu \mathrm{M}$ rosuvastatin $(p<0.01)$. In both cell lines, 
a)
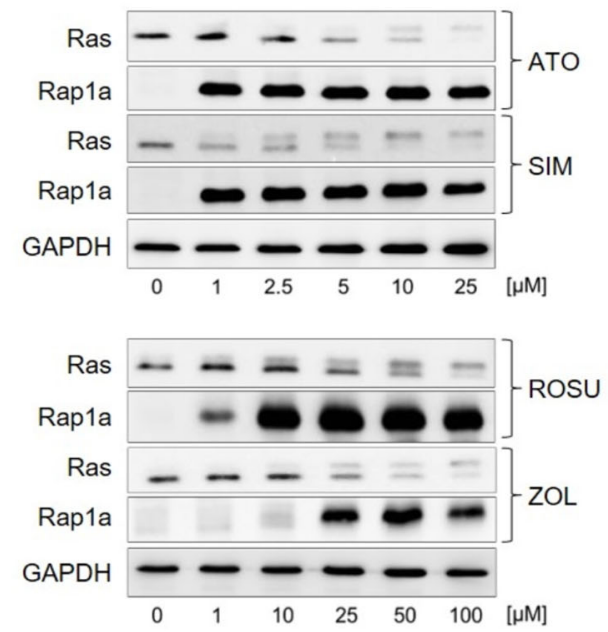

A2780
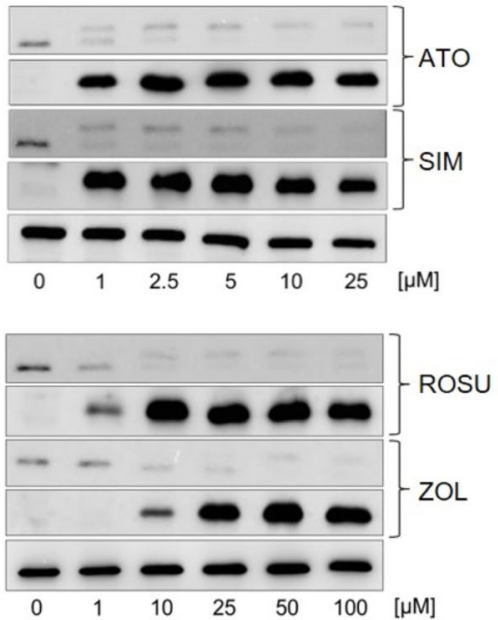

b)
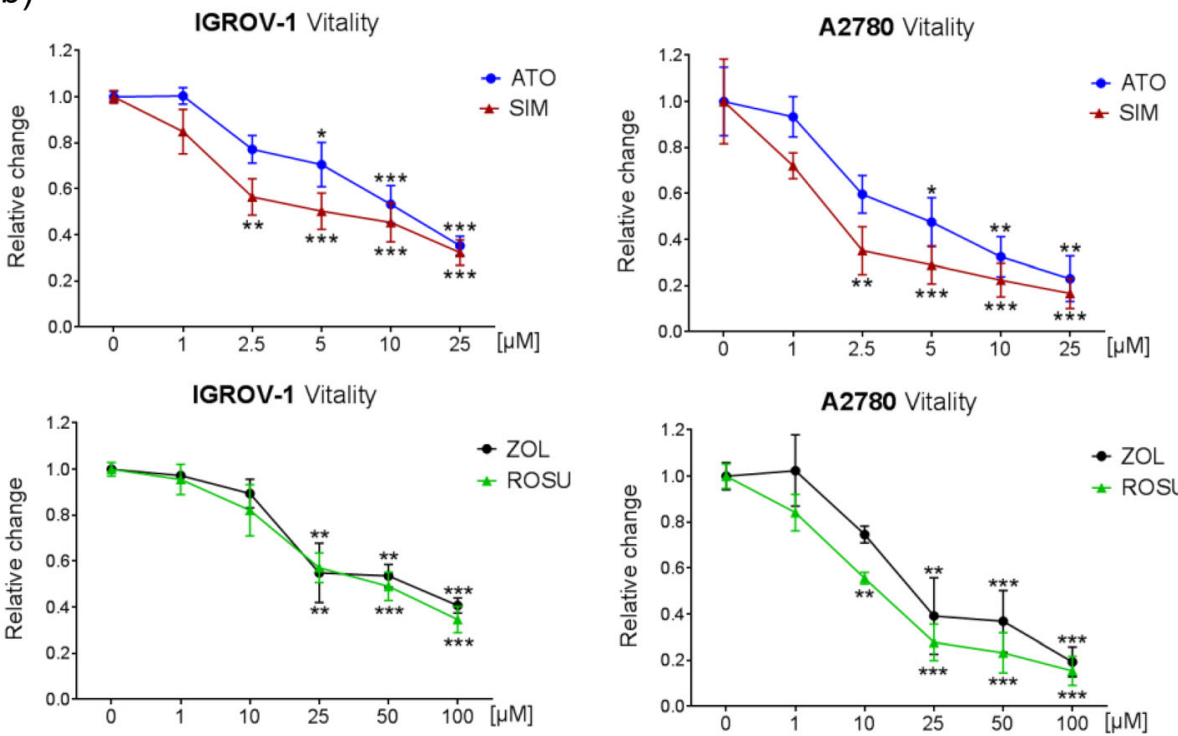

Fig. 1 The inhibition of the mevalonate pathway suppresses cell vitality in human IGROV-1 and A2780 ovarian cancer cells. a IGROV-1 and A2780 cells were treated for $48 \mathrm{~h}$ and $24 \mathrm{~h}$, respectively, with increasing concentrations of atorvastatin (ATO), simvastatin (SIM), rosuvastatin (ROSU) or zoledronic acid (ZOL). The inhibition of the mevalonate pathway was assessed by detection of Ras-related protein 1 (Rap1a, ungeranylated form is detected) and unfarnesylated Rat sarcoma (Ras; upper band) using Western blot. Glyceraldehyde-3-phosphate dehydrogenase (GAPDH) was used as loading control. The figures show representative blots which were cropped from original images. Full-length blots are presented in Suppl. Fig. 5. Images were detected using GelCapture 7.0.18 software. b IGROV-1 and A2780 cells were treated with increasing concentrations of ATO, SIM, ROSU, or ZOL for $48 \mathrm{~h}$. Cell vitality was assessed by CellTiterBlue ${ }^{\oplus}$ assay. Data are shown as mean \pm SEM of at least three individual experiments. ${ }^{*} p<0.05 ;{ }^{* *} p<0.01$; ${ }^{* * *} p<0.001$ )

simvastatin was the most potent of the tested statins and induced a 3-folds increase of caspases activity in IGROV-1 cells and a 4.5 -folds increase in A2780 at the lowest concentration of $1 \mu \mathrm{M}$ (Fig. 2a). Higher concentrations of zoledronic acid $(>25 \mu \mathrm{M})$ were necessary to achieve significant results. Apoptosis was confirmed by assessment of cleaved (poly-ADP) ribose polymerase (cPARP) in both cell lines (Fig. 2a). A2780 cells were more sensitive to the treatments with a strong accumulation of cPARP already $24 \mathrm{~h}$ after treatment. Notably, the treatment of IGROV-1 cells also significantly suppressed the gene expression of the two anti-apoptotic genes B-cell lymphoma $2(B c l-2)$ and survivin (Svv). Whereas this suppressive effect was more pronounced on $S v v$ using any statin (by up to $-90 \%$ gene expression; Fig. 2b; $p<0.001$ ), zoledronic acid had a stronger effect 
a)
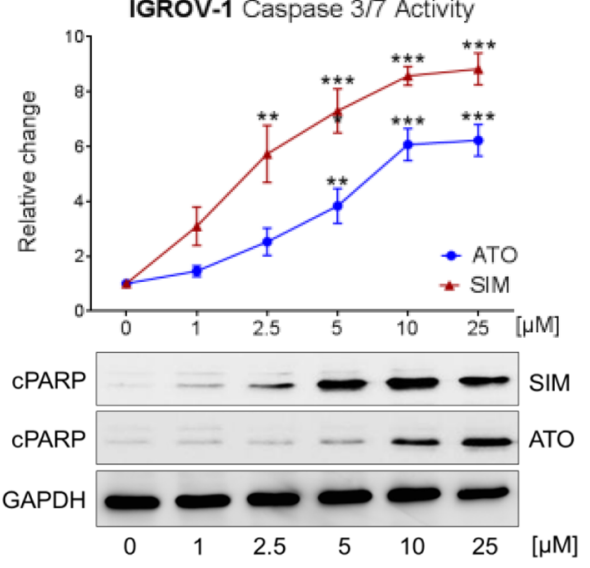

A2780 Caspase $3 / 7$ Activity
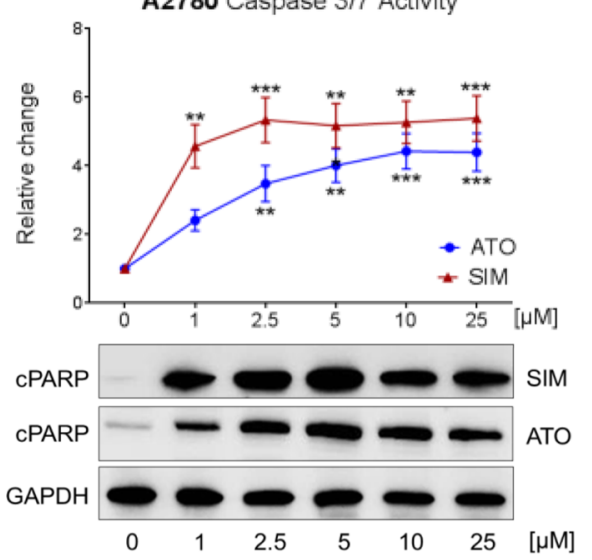

b)
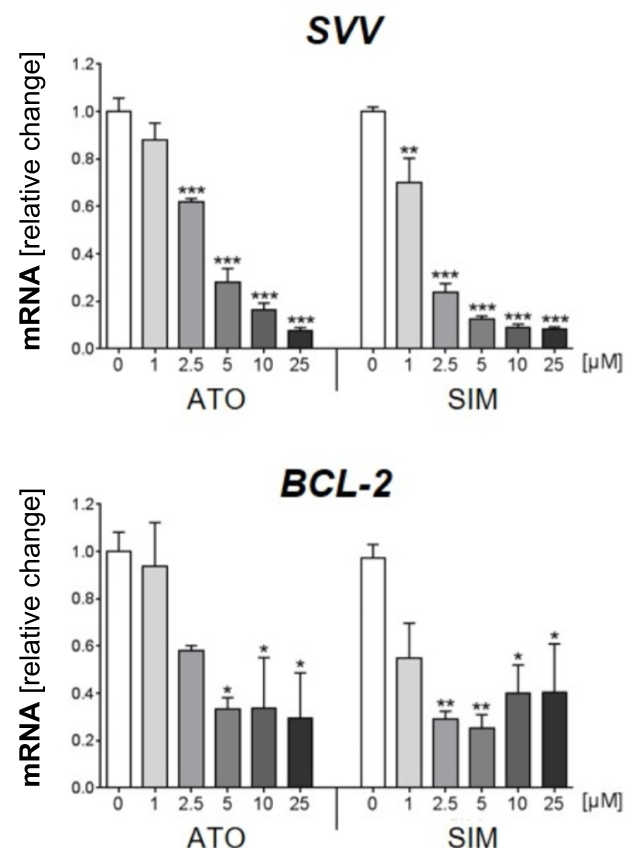

IGROV-1 Caspase 3/7 Activity
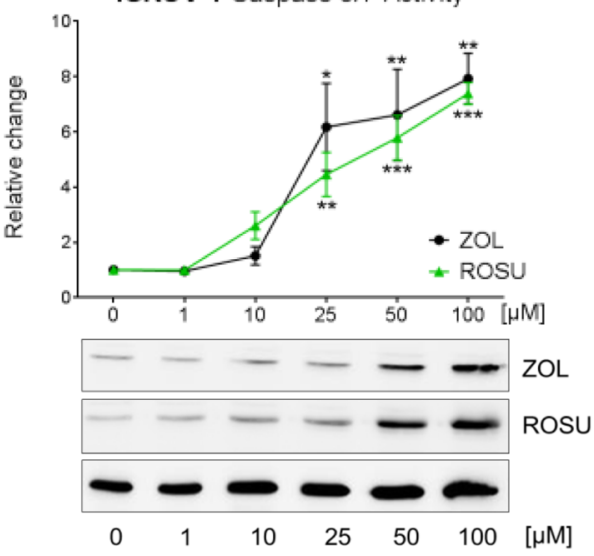

A2780 Caspase $3 / 7$ Activity
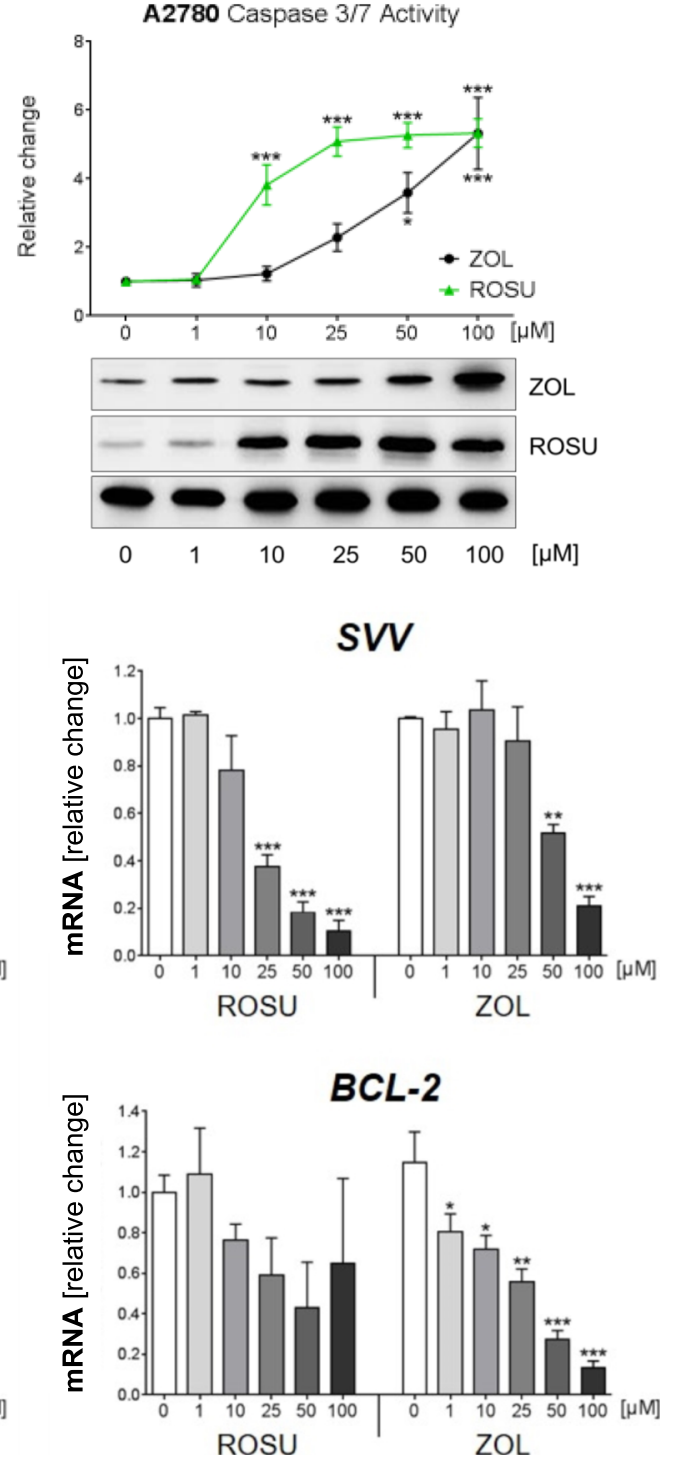

Fig. 2 (See legend on next page.) 
(See figure on previous page.)

Fig. 2 The inhibition of the mevalonate pathway induces apoptosis in human IGROV-1 and A2780 ovarian cancer cells. a Anti-tumor effects mediated by atorvastatin (ATO), simvastatin (SIM), rosuvastatin (ROSU) or zoledronic acid (ZOL) were assessed by the Caspase $3 / 7$ Glo ${ }^{\oplus}$ assay after treatment of IGROV-1 and A2780 cells for $48 \mathrm{~h}$. Induction of apoptosis was further confirmed using Western blot based detection of cleaved poly (ADP-ribose) polymerase (CPARP) $48 \mathrm{~h}$ after treatment of IGROV-1 cells and $24 \mathrm{~h}$ after treatment of A2780 cells, respectively. The equal protein loading is shown by detection of glyceraldehyde-3-phosphate dehydrogenase (GAPDH). The figures show representative blots which were cropped from original images. Full-length blots are presented in Suppl. Fig. 6. Images were detected using GelCapture 7.0.18 software. b Analysis of the expression of the anti-apoptotic genes survivin (SW) and B-cell lymphoma 2 (BCL-2) by quantitative real-time-PCR $48 \mathrm{~h}$ after treatment of IGROV-1 cells with ATO, SIM, ROSU and ZOL. Data are shown as mean \pm SEM of at least three individual experiments. $\left({ }^{*} p<0.05 ;{ }^{* *} p<0.01 ;{ }^{* * *} p<0.001\right)$

on $\mathrm{Bcl}$-2 expression ( $-85 \%$ gene expression; Fig. $2 \mathrm{~b} ; \mathrm{p}<$ 0.001 ). Rosuvastatin was not able to significantly reduce $B c l-2$ expression. $B c l-2$ levels in A2780 cells were not affected by any of the mevalonate pathway inhibitors (Suppl. Fig. 2). By contrast, Svv expression was decreased by all agents, with simvastatin being the most potent one, which suppressed $S v v$ gene expression by $50 \%$ at a concentration of $2.5 \mu \mathrm{M}$ (Suppl. Fig. 2; $p<0.01$ ).

\section{The anti-tumor effects of statins and zoledronic acid in IGROV-1 and A2780 cells are mediated by an inhibited geranylgeranylation}

The mevalonate pathway is essential for farnesylation and geranylgeranylation of proteins by the production of FPP and GGPP. To distinguish between the role of one or the other prenylation route in the anti-tumor effects of statins and zoledronic acid in ovarian cancer, rescue experiments were performed. IGROV-1 cells were supplemented with FPP or GGPP to specifically rescue farnesylation or geranylgeranylation during mevalonate pathway inhibition. The individual efficacy of both supplements to recover farnesylation or geranylgeranylation upon mevalonate pathway inhibition was proven for the treatments with simvastatin or zoledronic acid (Suppl. Fig. 3a). Only GGPP was able to recover suppressed cell vitality (Fig. 3a) or activation of caspases 3/7 (Fig. 3b) upon the treatments with any statin and zoledronic acid $(p<0.001)$. FPP only partially rescued the observed effects. Similar observations were made in A2780 cells, where loss of vitality by mevalonate pathway inhibition was almost fully rescued by GGPP but not FPP supplementation (Suppl. Fig. 3b; $p<$ 0.001). Hence, blocked geranylgeranylation appeared more critical in mediating the anti-tumor effects by mevalonate pathway inhibition in IGROV-1 cells.

\section{Statins and zoledronic acid suppress pro-inflammatory cytokines in IGROV-1 cells}

Several mediators support the growth, progression, and metastasis of human ovarian cancer cells. The proinflammatory cytokines IL-6, IL- 8 and TNF- $\alpha$ are commonly present in the ascites of ovarian cancer patients [53, 54]. Therefore, the expression of these tumor-promoting genes was assessed in IGROV-1 cells $24 \mathrm{~h}$ after treatments. All statins and zoledronic acid significantly suppressed gene expression of TNF $\alpha$ and IL8 (Fig. 4a; $p<0.001$ ). For TNF $\alpha$, a significant reduction was already achieved upon $1 \mu \mathrm{M}$ of simvastatin or atorvastatin, whereas $10-25 \mu \mathrm{M}$ rosuvastatin or zoledronic acid were necessary to obtain comparable results (Fig. 4a). In general, higher concentrations of all agents were needed to significantly block IL8 expression. Moreover, statins and zoledronic acid dose-dependently and significantly inhibited gene expression of IL6 (-95\%; Fig. 4b; $p<0.001$ ). Again, a strong inhibitory effect was already seen with $1 \mu \mathrm{M}$ simvastatin. These results were reflected by IL-6 protein levels measured in the supernatants of IGROV-1 treated cells. Lower concentrations of atorvastatin and simvastatin $(5 \mu \mathrm{M})$ achieved a significant decrease of IL-6 protein by $80 \%$, whereas only higher levels of rosuvastatin and zoledronic acid $(25 \mu \mathrm{M})$ led to comparable results (Fig. 4b; $p<0.001$ ).

\section{Statins and zoledronic acid suppress tumor-promoting regulators in IGROV-1 and A2780 cells}

An inflammatory microenvironment in ovarian cancer accelerates the dissemination of tumor cells and metastases. These events are facilitated by an increased vasculature permeability and by epithelial-mesenchymal transition. In this regard, the pro-angiogenic vascular endothelial growth factor (VEGF) and the pro-migratory transforming growth factor (TGF)- $\beta 1$ are considered key elements contributing to tumor progression $[9,55]$. Expression of VEGF was measured when IGROV-1 and A2780 cells were treated for 24 $\mathrm{h}$, whereas TGF $\beta 1$ expression was analyzed after $48 \mathrm{~h}$ of treatments in IGROV-1 cells, since mild or no effects were observed after $24 \mathrm{~h}$ (data not shown). All statins significantly reduced VEGF and TGF 1 gene expression in IGROV-1 cells by up to $60 \%$ (Fig. 5a; $p<0.001$ ). Again, simvastatin was the most effective statin, leading to a $40 \%$ reduction of VEGF at $1 \mu \mathrm{M}(p<0.001)$, and of TGF $\beta 1$ at $2.5 \mu \mathrm{M}(p<0.01)$. The effects were not enhanced by higher concentrations. Rosuvastatin proved to be effective in lowering VEGF expression when used at $10 \mu \mathrm{M}(p<0.001)$, and mediated a significant TGF 1 reduction only at the highest concentrations $(p<0.01)$. Zoledronic acid failed to induce a significant response. VEGF expression was also seen to be significantly decreased in A2780 cells upon statins, but not upon treatment with zoledronic acid (- 50\%; Fig. 5b; $p<0.001)$. 
a)

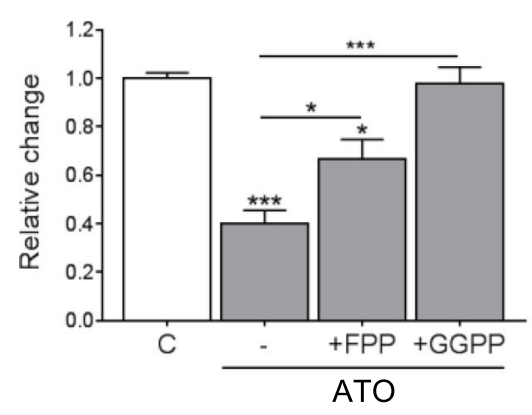

IGROV-1 Vitality
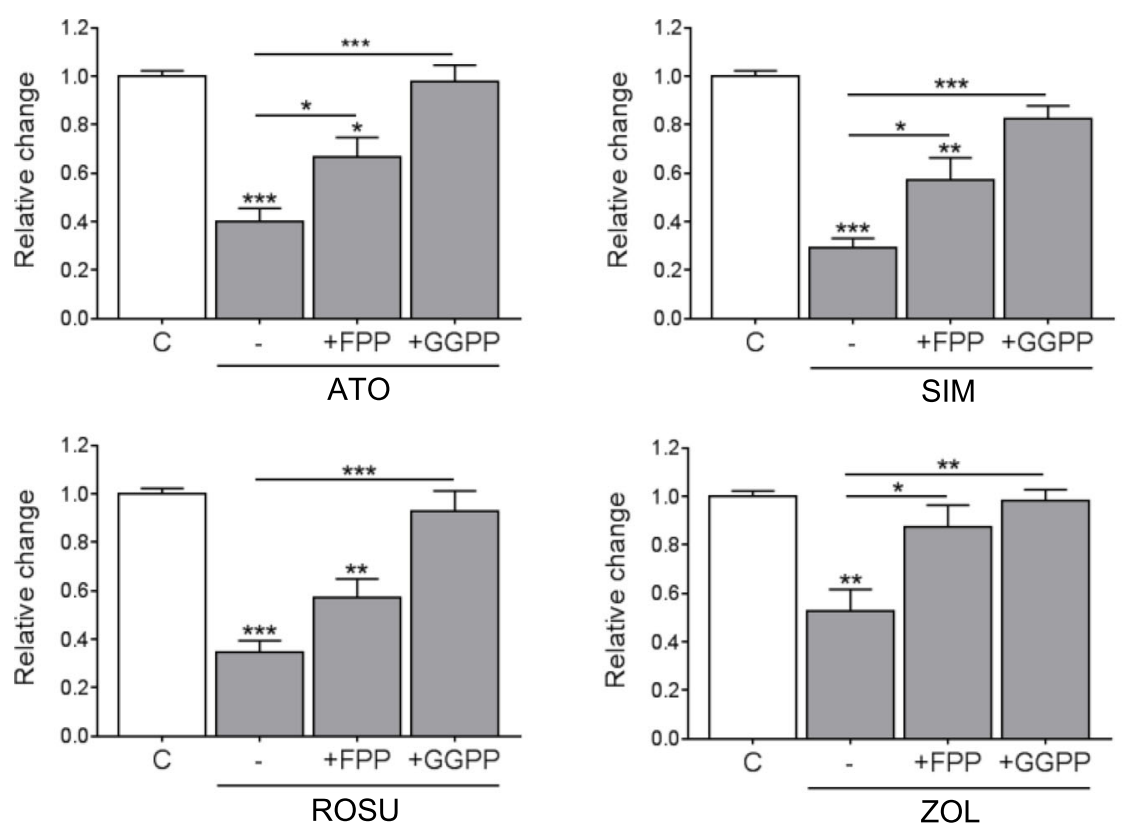

b)
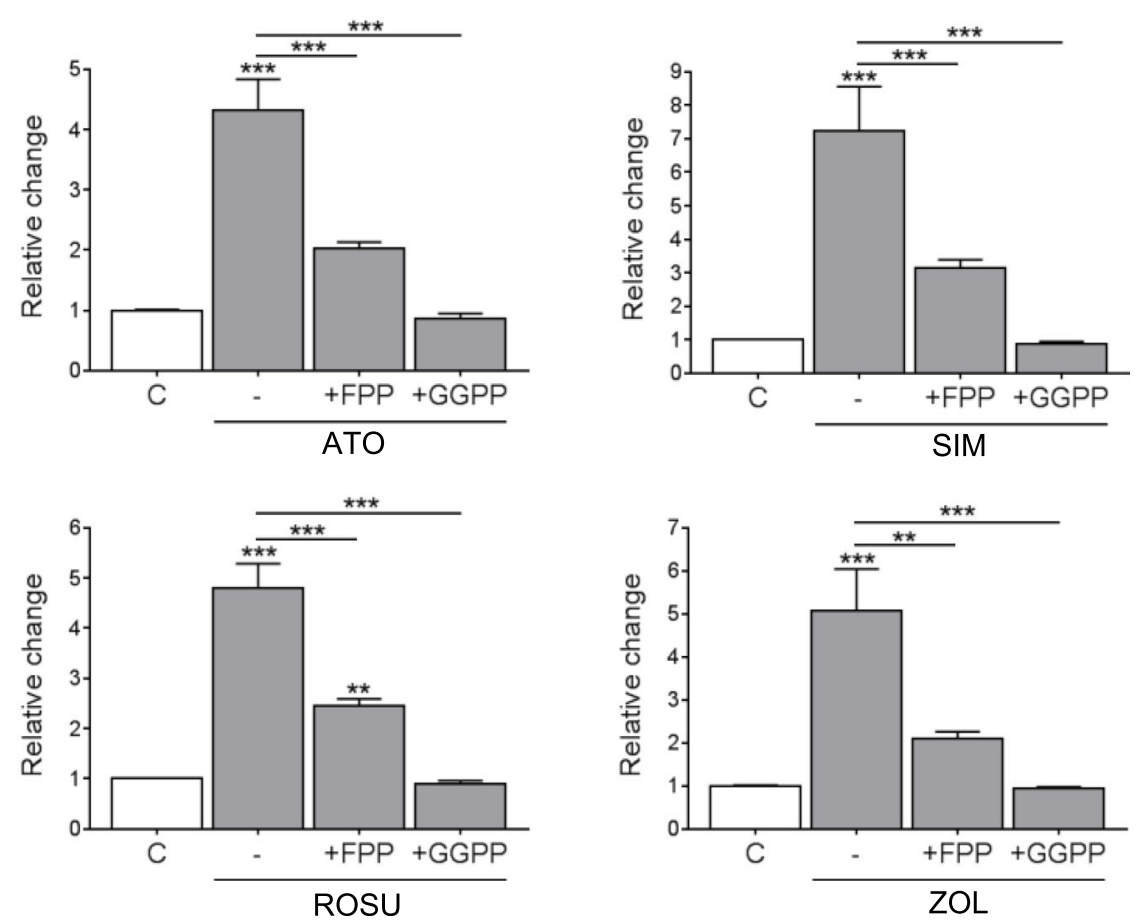

Fig. 3 The anti-tumor effects by simvastatin (SIM), atorvastatin (ATO), rosuvastatin (ROSU) and zoledronic acid (ZOL) in IGROV-1 cells are mediated by inhibited geranylgeranylation. IGROV-1 cells were treated with ATO $(10 \mu \mathrm{M})$, SIM $(10 \mu \mathrm{M})$, ROSU $(50 \mu \mathrm{M})$ or ZOL $(50 \mu \mathrm{M})$, and supplemented with $10 \mu \mathrm{M}$ of either farnesyl pyrophosphate (FPP) or geranylgeranyl pyrophosphate (GGPP) for $48 \mathrm{~h}$. a Cell vitality was assessed by CellTiterBlue ${ }^{\oplus}$ assay. b Apoptosis was measured by the Caspase $3 / 7 \mathrm{Gl}{ }^{\oplus}$ assay. Data are shown as mean \pm SEM of at least three individual experiments. $\left({ }^{*} p<\right.$ $0.05 ;{ }^{* *} p<0.01 ;{ }^{* * *} p<0.001$ vs. respective control (C) or vs. respective treatment $\left.(-)\right)$ 
a)

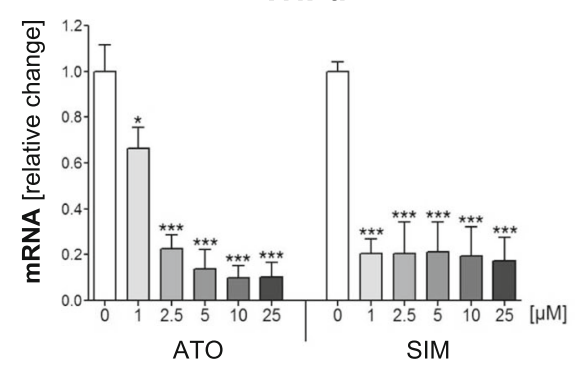

IL8

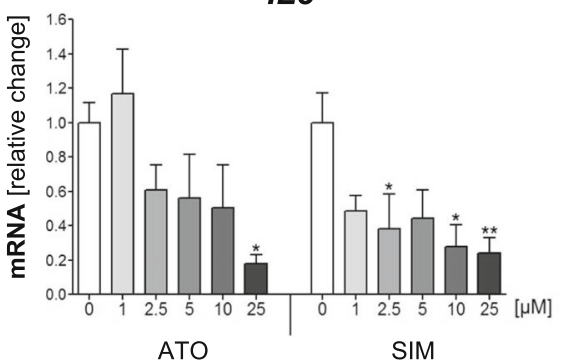

b)

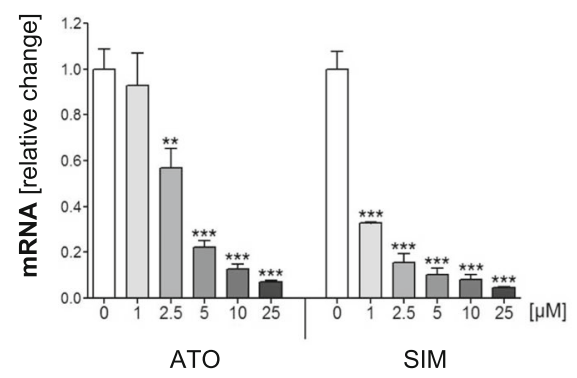

IL6 (supernatant)

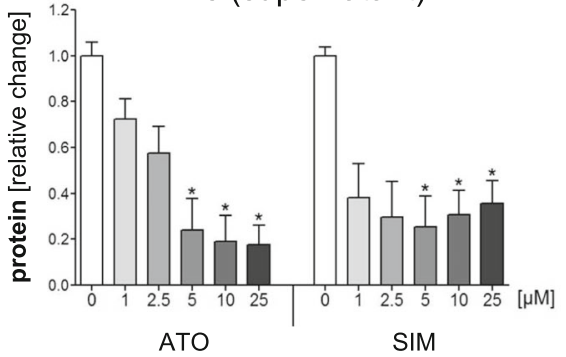

$T N F a$

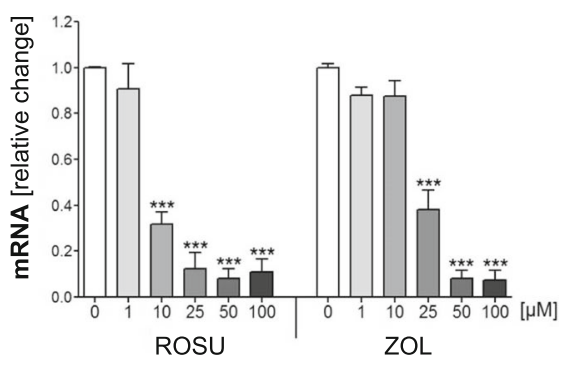

IL8

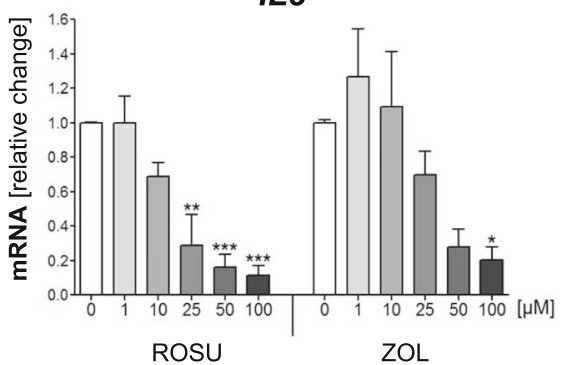

IL6

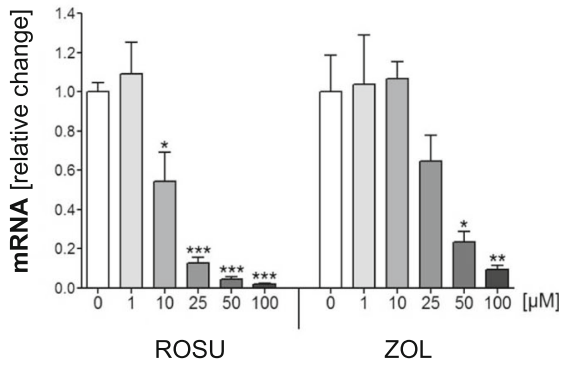

IL6 (supernatant)

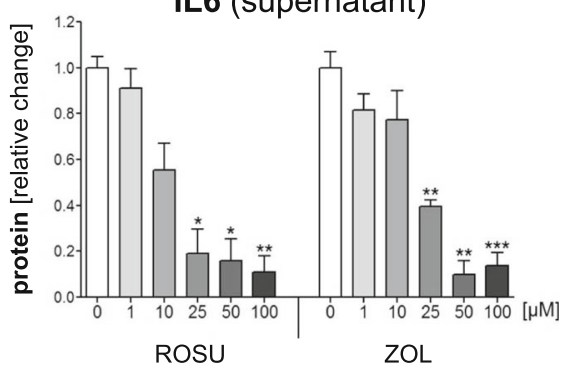

Fig. 4 Statins and zoledronic acid (ZOL) suppress gene and protein expression of pro-inflammatory cytokines in IGROV-1 cells. IGROV-1 cells were treated with increasing concentrations of atorvastatin (ATO), simvastatin (SIM), rosuvastatin (ROSU) or ZOL for $24 \mathrm{~h}$. Expression of tumor necrosis factor (TNF)a and interleukin (IL)8 was assessed by quantitative real-time-PCR (a). Expression of IL6 was assessed by quantitative real-time-PCR after $24 \mathrm{~h}$ of treatments (b). Supernatants of treated IGROV-1 cells were collected after $48 \mathrm{~h}$ of treatments and analyzed for IL-6 protein levels by human IL-6 ELISA (b.) Data are shown as mean \pm SEM of at least three individual experiments. ${ }^{*} p<0.05$; ${ }^{* *} p<0.01 ;{ }^{* * *} p<0.001 \mathrm{vs}$. respective control $\left.(0 \mu \mathrm{M})\right)$

\section{Simvastatin induces apoptosis in cisplatin-resistant A2780cis cells}

One of the most challenging limitations in treating human ovarian cancer is the resistance of cancer cells to platinum [22]. Therefore, the anti-tumor effects mediated by statins and zoledronic acid were analyzed in the cisplatin-resistant cell line A2780cis, in direct comparison with the parental cisplatin-sensitive A2780 cell line. The relative cisplatin resistance of A2780cis cells was confirmed by showing that cisplatin affected vitality and apoptosis at higher doses, whereas parental A2780 cell vitality was already suppressed at low concentrations 
a)
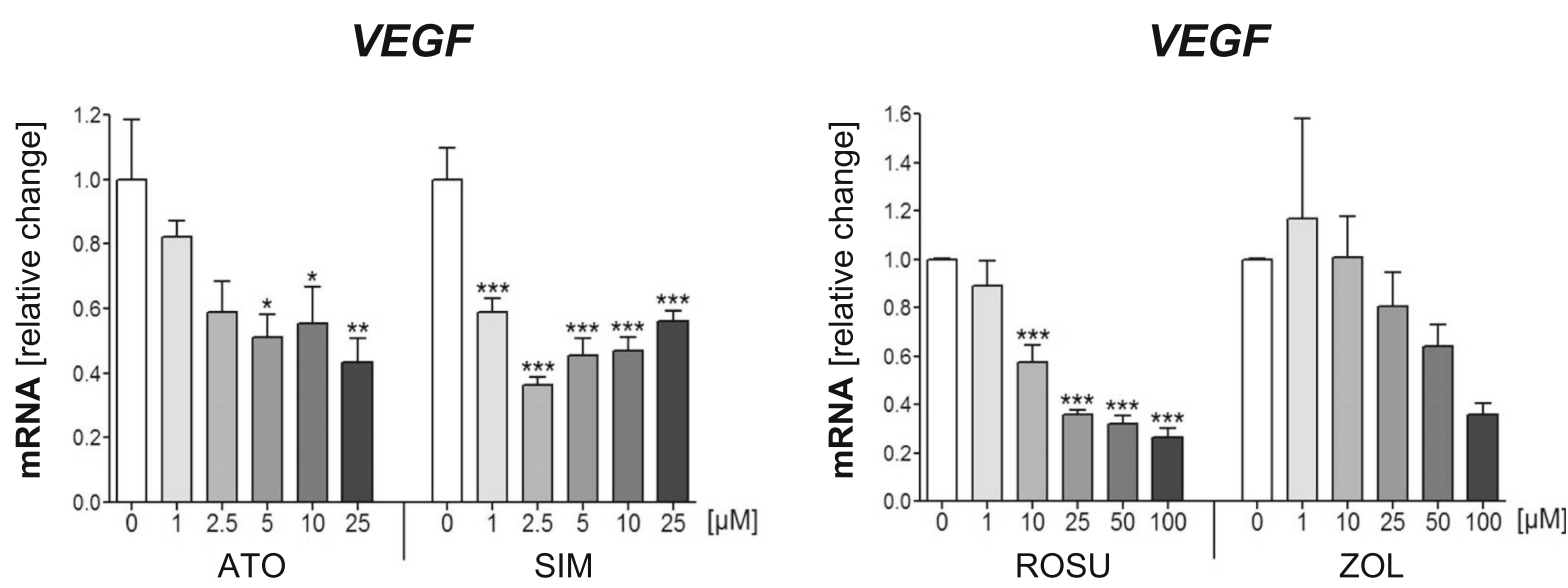

TFGß1

b)
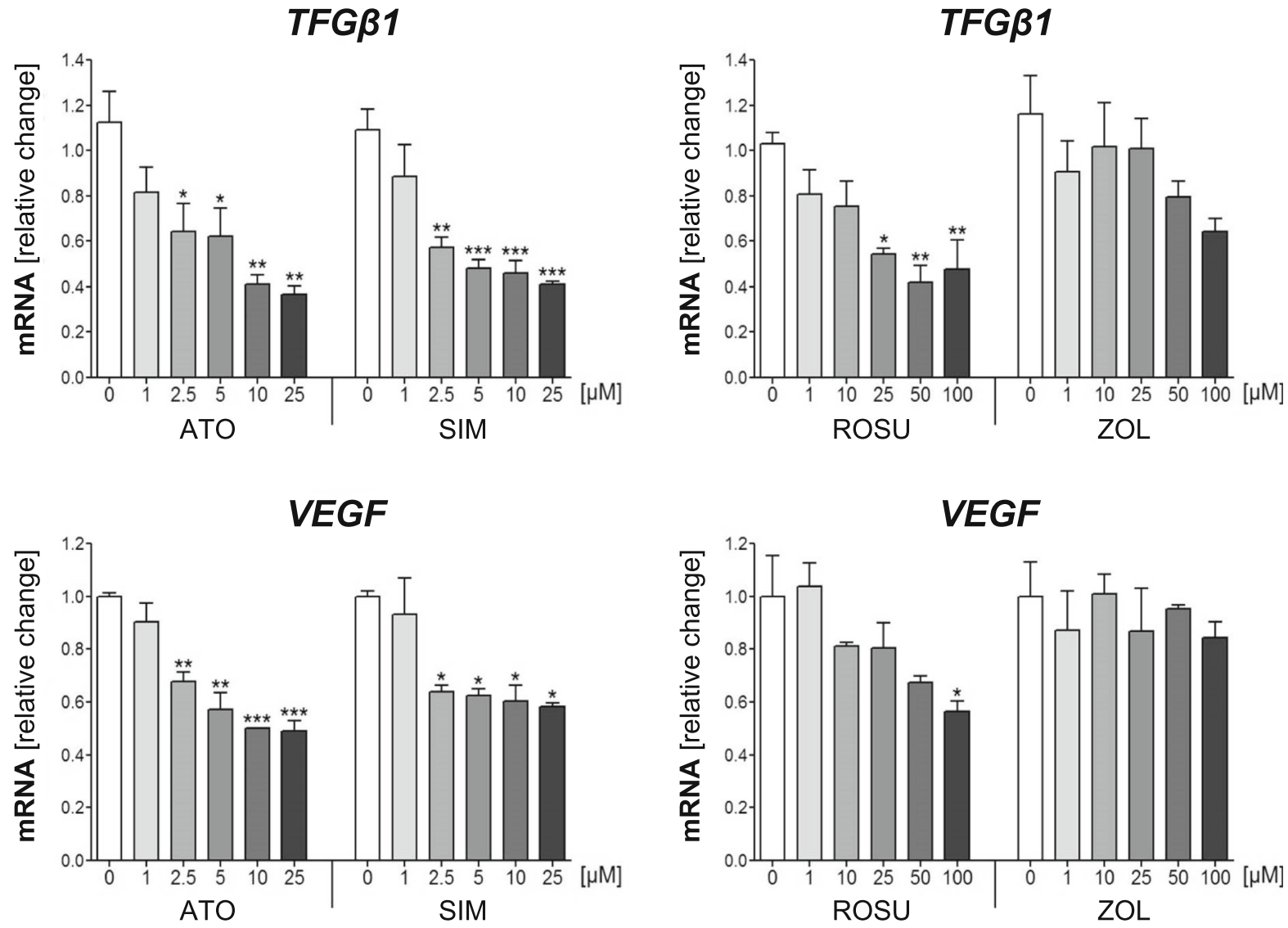

Fig. 5 Statins reduce the expression of vascular endothelial growth factor (VEGF) and transforming growth factor (TGF)- $\beta 1$ in IGROV-1 and A2780 cells. IGROV-1 (a) and A2780 (b) cells were treated with increasing concentrations of atorvastatin (ATO), simvastatin (SIM), rosuvastatin (ROSU) or zoledronic acid (ZOL). Expression of VEGF ( $24 \mathrm{~h})$ and TGF $\beta 1$ ( $48 \mathrm{~h}$ ) was assessed by quantitative real-time-PCR. Data are shown as mean \pm SEM of at least three individual experiments. $\left({ }^{*} p<0.05 ;{ }^{* *} p<0.01 ;{ }^{* * *} p<0.001\right.$ vs. respective control $\left.(0 \mu \mathrm{M})\right)$

(Suppl. Fig. 4a). As previously demonstrated, the treatment of A2780 cells with mevalonate pathway inhibitors suppressed cell vitality $(-90 \%$; Fig. 6a; $p<0.001)$ and induced caspase $3 / 7$ activation by up to 5 -folds (Fig. 6b; $p<0.001)$. Simvastatin and atorvastatin were more potent compared to rosuvastatin and zoledronic acid as significant anti-tumor effects were achieved at low concentrations $(1-2.5 \mu \mathrm{M})$. A2780cis cells showed relative resistance to low concentrations of simvastatin, atorvastatin, and zoledronic acid (Fig. 6). Here, vitality was 
a)

\section{Vitality}

ATO

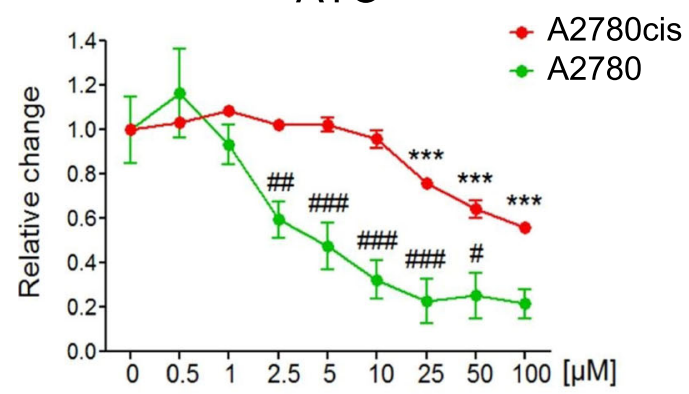

ROSU

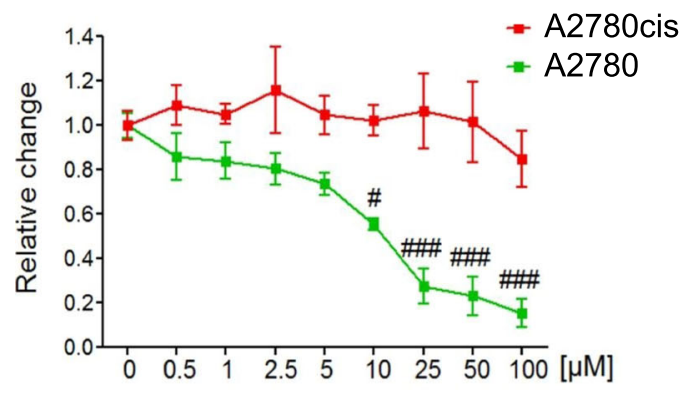

SIM

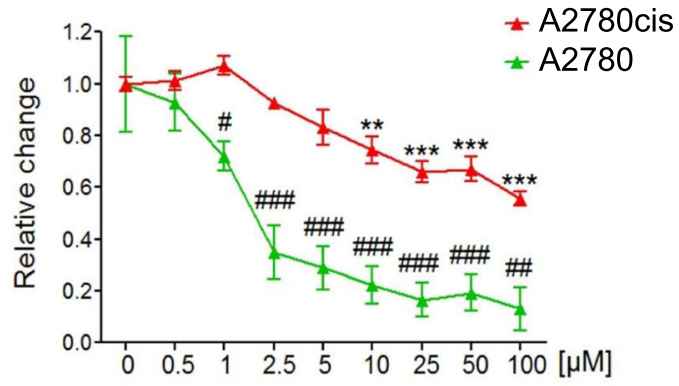

ZOL

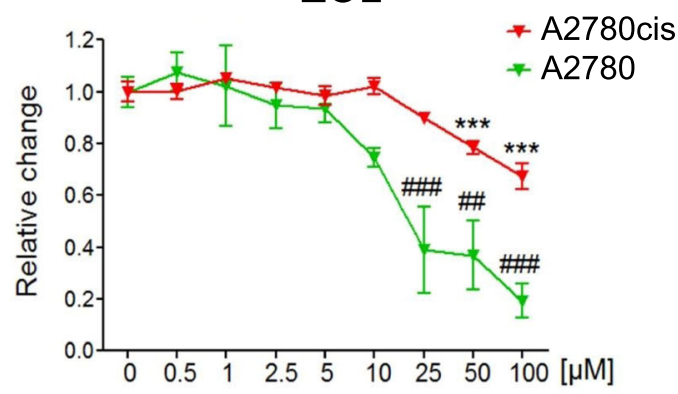

b)

Caspase $3 / 7$ activity

ATO

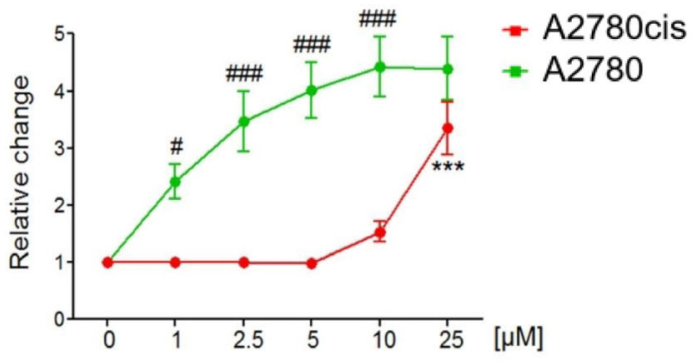

ROSU

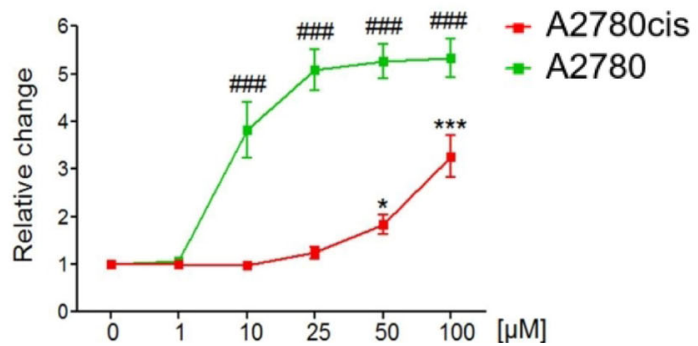

SIM

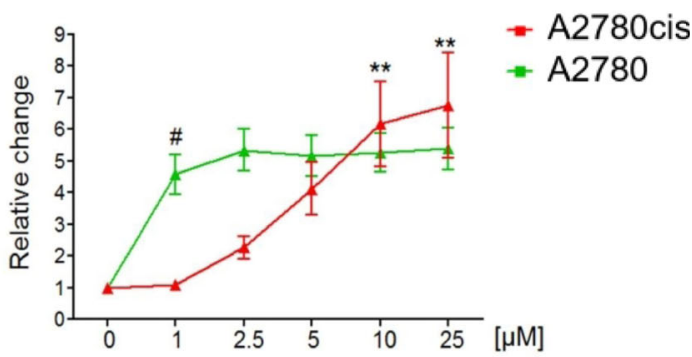

ZOL

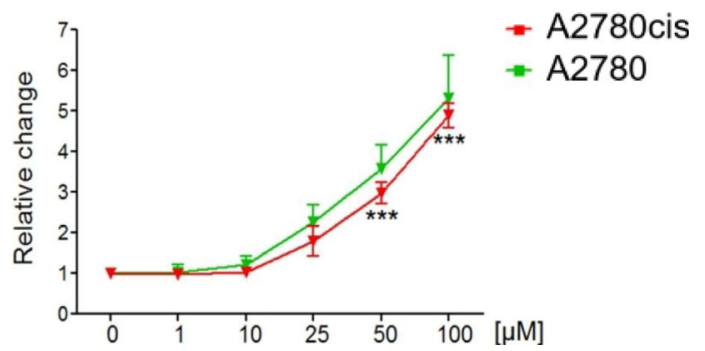

Fig. 6 (See legend on next page.) 
(See figure on previous page.)

Fig. 6 Cisplatin-resistant A2780cis cells show relative resistance to statins and zoledronic acid (ZOL) compared to parental A2780 cells. A2780 and A2780cis cells were treated with increasing concentrations of atorvastatin (ATO), simvastatin (SIM), rosuvastatin (ROSU) or (ZOL) for 48 h. Cell vitality (a) and apoptosis (b) were assessed by CellTiterBlue ${ }^{\oplus}$ and Caspase 3/7 Glo assays. Statistics refers to A2780cis cells. Data are shown as mean \pm SEM of at least three individual experiments. $\left({ }^{*} p<0.05 ;{ }^{* *} p<0.01 ;{ }^{* * *} p<0.001\right.$ vs. respective control $(0 \mu \mathrm{M})$. \#p $<0.05 ; \# \# p<0.01$; \#\#\#p< 0.001 vs. respective value of A2780 treated cells)

significantly decreased only at higher concentrations from 10 to $100 \mu \mathrm{M}(-30-40 \%$; Fig. 6a; $p<0.001)$. These effects differed significantly from the loss of vitality achieved in A2780 cells that was attained already at lower concentrations $(1-10 \mu \mathrm{M} ; p<0.001)$. Rosuvastatin failed to induce significant effects on cell vitality in A2780cis cells. For caspase 3/7 activation, high concentrations of rosuvastatin and atorvastatin $(25-100 \mu \mathrm{M})$ induced a 3-folds increase of apoptosis in A27080cis cells (Fig. 6b; $p<0.001$ ). Notably, although higher concentrations $(10-25 \mu \mathrm{M})$ were required, simvastatin induced a similar induction of caspases $3 / 7$ activity in A2780cis cells compared to A2780 cells (6-folds; Fig. 6b; $p<0.01$ ). These observations were confirmed by detection of cPARP showing a dose-dependent induction of apoptosis, which was accompanied by a significant suppression of $S v v$ gene expression in A2780cis cells $(-80 \%$; Suppl. Fig. 4b; $p<0.001)$. Here, simvastatin was able to block the mevalonate pathway even at concentrations as low as $1 \mu \mathrm{M}$ (Suppl. Fig. 4b). Moreover, the pattern of caspase $3 / 7$ activation upon treatment with zoledronic acid was similar between cisplatin-resistant and parental cells (6-folds; Fig. 6b; $p<0.01$ ). These results demonstrate that cisplatin-resistant A2780cis cells show relative resistance to mevalonate pathway inhibitors, but respond with a similar induction of significant apoptosis compared to cisplatin-sensitive A2780 cells upon treatment with simvastatin and zoledronic acid.

\section{Discussion}

Among human gynecologic malignancies, ovarian cancer is the most lethal one [56]. The vast majority of patients are diagnosed at an advanced stage, when the long term survival rates are found to be as low as 20-30\% [5]. Current therapeutic options are limited, particularly for advanced ovarian cancer, because of recurrence, metastasis and chemo-resistance to primary treatments or secondarily acquired resistance [10]. Statins and N-BP as inhibitors of the mevalonate pathway have been widely studied for their pleiotropic anti-tumor properties [24].

The rationale for targeting the mevalonate pathway in ovarian cancer is underpinned by the evidence of a role of the mevalonate pathway in ovarian cancer tumorigenesis. The HMGCR enzyme is overexpressed in several human ovarian cancer cell lines, including IGROV-1 and A2780 [29]. Moreover, late-stage metastatic ovarian cancer cells show a marked molecular reprogramming with upregulation of several mevalonate pathway genes including HMGCR [57]. High levels of cholesterol have been linked to an increased risk of developing ovarian and other cancer entities [33]. A number of retrospective and case-control studies have shown a significant association between pre- and/or post-diagnostic use of statins and a reduced overall as well as ovarian cancer-specific mortality have been described $[58,59]$. A reduced risk of developing ovarian or endometrial cancers was seen in patients prescribed with bisphosphonates for more than 1 year before the diagnosis [60].

In our study, we demonstrate that statins and the N-BP zoledronic acid reduce cell vitality and induce apoptosis in the ovarian cancer cell lines A2780 and IGROV-1. These observations match with studies describing similar effects in vitro and in vivo in a number of human malignancies [57, 61-72]. In the present study, the lipophilic statins atorvastatin and simvastatin were more potent than the hydrophilic rosuvastatin which is in line with studies in breast and additional ovarian cancer cell lines, including Hey 1B and OVCAR-3 [52, 63, 73-75]. The differences in the chemical structure, the transport into cells via passive membrane diffusion or via transporters and the varying potential to alter the sterol metabolism within tumor cells may account for variances in the anti-tumor effects exerted by different statins $[41,63]$.

Not only did the individual effects among the used statins differ, but also the sensitivity of the used cell lines, which is a known phenomenon in human cancer cell lines $[52,76,77]$. This could be due to differences in the molecular profile of A2780 and IGROV-1 cells. Although both of them are estrogen receptor negative, A2780 cells carry few mutations, whereas IGROV-1 are considered as hyper-mutated and carry both familial and sporadic mutations [78]. Moreover, simvastatin exerted significant effects on apoptosis in cisplatin-resistant A2780cis cells, although higher concentrations compared to parental A2780 cells were necessary, indicating a relative cross-resistance. Future studies might also investigate potential statin resistance mechanisms and biomarkers of statin or N-BP sensitivity and whether these may cross-interfere with mechanisms of cisplatin resistance. We and others have demonstrated a restorative feedback loop by induction of the statin targeting enzyme, the HMGCR, as a mediator of statin resistance in human breast and prostate cancer as well as multiple myeloma cells $[52,79,80]$. Similar mechanisms might 
occur in ovarian cancer cells, especially as cisplatin and simvastatin induce a strong accumulation of HMGCR in ovarian cancer cells $[81,82]$. In times of personalized medicine, it would be greatly relevant to identify patients with those molecular subtypes, that would mostly benefit from a statin or N-BP therapy, individually or in combination with chemotherapy, as well as to define the optimal therapeutic window.

We demonstrated that the cytotoxic effects by statins and zoledronic acid in IGROV-1 and A2780 cells were mediated by an inhibited geranylgeranylation, rather than by an inhibited farnesylation. These observations were made in breast cancer cells using the same agents [51]. In mice bearing Ovcar-4 ovarian cancer xenografts, geranylgeraniol limits the anti-tumor effects of pitavastatin [29]. The underlying mechanisms are potentially mediated by a disrupted function of geranylgeranylated Rho proteins. Alendronate inhibits ovarian cancer cell migration through an inhibited geranylgeranylation and Rho protein activation [83]. In addition, pitavastatin alters the subcellular localization of RhoA, CDC42 and Ras in several ovarian cancer cell lines [77].

The treatments with statins and zoledronic acid also significantly reduced the expression of the anti-apoptotic genes $B c l-2$ and $S v v$, even in chemo-resistant A2780cis cells, which is in line with studies in breast, colorectal, and prostate cancer [84-87]. Bcl-2 as well as $S v v$ have been shown to be overexpressed in ovarian carcinomas and are associated with chemo-resistance and a worse prognosis [88-92]. The suppression of both genes by statins and zoledronic acid offers a potential strategy to overcome such resistance. Platinum resistance is a major problem in the treatment of ovarian cancer, for which different mechanisms account such as increased drug efflux and inactivation, the ability to repair platinum-DNA adducts, or overexpression of anti-apoptotic regulators [93]. Additional studies might investigate, as to whether or not statins and N-BP modulate anti-apoptotic genes in these cells and if a concomitant treatment with platinum would re-sensitize the cells and induce cytotoxicity as seen in cisplatin-resistant SKOV3 cells [94]. The potential advantage of such a combinatory approach is the reduction of individual concentrations without the loss or even with the increase of therapeutic effects and reduced side effects such as nephro- and neurotoxicity by cisplatin [11].

Our study also demonstrates, that especially statins significantly suppressed TNF- $\alpha, T F G-\beta 1 I L-6, I L-8$ and VEGF in IGROV-1 and A2780 cells. These factors play central roles in the accumulation of peritoneal fluid, inflammation, and angiogenesis, as well as in supporting tumor promotion and metastases [54, 95-101]. Moreover, all of them are overexpressed and associated with chemo-resistance and a poor prognosis in affected patients with ovarian cancer [54, 95-101]. The constitutive expression of IL6 by ovarian cancer cells stimulates TAMs of the tumor microenvironment thereby promoting tumor growth [102]. IL-6 also promotes the production of pro-angiogenic factors, like VEGF and IL-8 [96] and the latter itself drives cell motility [103]. Constitutive secretion of TNF- $\alpha$ leads to the further release of IL-6, VEGF, and other factors that concomitantly sustain the vicious cycle of malignant ascites [9, 54]. Targeting these tumorpromoting soluble factors offers a therapeutic strategy in ovarian cancer and might modulate the response of chemo-resistant tumor cells to chemotherapy. VEGF suppression was seen to reduce tumor burden and ascites formation in several preclinical studies [104]. Successful translation of these findings has led to the development and evaluation of the VEGF targeting antibody bevacizumab in clinical trials and its approval for the use in patients with ovarian cancer $[13,14]$. Pharmacological inhibition of IL-6 has also been positively evaluated in preclinical and clinical studies [105]. The knockdown of IL-6 and IL-8 was shown to sensitize the tumor cells to cisplatin treatment in lung and ovarian cancer, respectively [106, 107]. Additional in vivo models using chemosensitive and -resistant ovarian cancer cell lines are necessary to evaluate the effects of statins and zoledronic acid, individually and in combination with chemotherapy, on these pro-tumorigenic factors.

Our study has several limitations, including the use of in vitro cell models which do not fully reflect the heterogenous pattern of molecular subtypes of human ovarian cancer. Moreover, the levels of statins that are reached in the serum of patients range between 0.002 and $0.1 \mu \mathrm{M}$ [108] and the maximum concentration of zoledronic acid administered to patients is $2 \mu \mathrm{M}$ [109]. Hence, the clinically achievable concentrations of these agents within tumor tissues and ascites might be too low for direct antitumor effects. However, the clonogenic assay revealed that even low concentrations of simvastatin significantly impaired the number of newly formed IGROV-1 colonies as a marker of the clonogenic potential. These findings might translate into effective anti-tumor effects of statins or even N-BP at low levels in the stage of single tumor cell dissemination to secondary sites and needs to be comprehensively analyzed in additional studies. In breast cancer, disseminated tumor cells can be eliminated with N-BP therapy and this is associated with an improved survival [110, 111]. For ovarian cancer, no trials exist that investigated adjuvant N-BP therapy in the context of single tumor cell dissemination.

\section{Conclusions}

In conclusion, our study demonstrates pleiotropic antitumor effects in ovarian cancer cells in vitro, ranging from loss of vitality, induction of apoptosis and 
suppression of mediators implicated in tumor cell survival, migration, angiogenesis, and metastasis. Additional preclinical and clinical studies to evaluate the full antitumor potential of statins and zoledronic acid are highly warranted.

\section{Supplementary information}

Supplementary information accompanies this paper at https://doi.org/10. 1186/s12885-020-07164-X.

Additional file 1: Suppl. Fig. 1. The colony-forming ability of IGROV1 cells is significantly impaired by simvastatin (SIM). IGROV1 cells were seeded in 6-well plates (200 cells/cavity) and treated with atorvastatin (ATO), SIM, rosuvastatin (ROSU) or zoledronic acid (ZOL) for 9-10 days. The resulting colonies were stained with a crystal violet solution. a. The crystal violet staining was eluted with $10 \%$ SDS and the absorbance was measured at $595 \mathrm{~nm}$. b. Counting of the colonies (absolute numbers). c. Representative pictures of the colonies. Data are shown as mean \pm SEM of at least three individual experiments. ${ }^{*} p<0.05$ vs. respective control (C).

Additional file 2: Suppl. Fig. 2. Statins and zoledronic acid ( $Z O L)$ do not modulate the expression of B-cell lymphoma 2 (BCL-2), but downregulate survivin (SW) in A2780 cells. A2780 cells were treated with increasing concentrations of atorvastatin (ATO), simvastatin (SIM), rosuvastatin (ROSU) or ZOL for $24 \mathrm{~h}$. Expression of $B C L-2$ and SW was assessed by real-time-PCR. Data are shown as mean \pm SEM of at least three individual experiments. ${ }^{*} p<0.05 ;{ }^{* *} p<0.01 ;{ }^{* * *} p<0.001$ vs. respective control $(0 \mu \mathrm{M})$.

Additional file 3: Suppl. Fig. 3. Farnesyl pyrophosphate (FPP) and geranylgeranyl pyrophosphate (GGPP) specifically rescue farnesylation or geranylgeranylation and vitality upon mevalonate pathway inhibition in IGROV1 and A2780 cells. a. IGROV1 cells were treated with simvastatin (SIM; $10 \mu \mathrm{M})$ or zoledronic acid (ZOL; $50 \mu \mathrm{M})$, and supplemented with either FPP $(50 \mu \mathrm{M})$ or GGPP $(50 \mu \mathrm{M})$. Farnesylation of Ras, geranylgeranylation of Rap1A and cleavage of poly (ADP-ribose) polymerase (CPARP) were assessed by western blotting. Glyceraldehyde3-phosphate dehydrogenase (GAPDH) was used as loading control. The figures show representative blots which were cropped from original images. Full-length blots are presented in Suppl. Fig. 7. Images were detected using GelCapture 7.0.18 software. b. A2780 cells were treated with atorvastatin (ATO), SIM, rosuvastatin (ROSU) or ZOL and supplemented with $10 \mu \mathrm{M}$ of either FPP or GGPP for $48 \mathrm{~h}$. Cell vitality was assessed by CellTiterBlue $^{\circledast}$ assay. Data are shown as mean \pm SEM of at least three individual experiments. ${ }^{*} p<0.05 ;{ }^{* *} p<0.01 ;{ }^{* * *} p<0.001$ vs. respective control (C). $\# p<0.05 ; \# \# p<0.01 ; \# \# p<0.001$ vs. respective treatment (-).

Additional file 4: Suppl. Fig. 4. A2780CIS are relative resistant to cisplatin and undergo apoptosis upon mevalonate pathway inhibition with simvastatin (SIM). a. A2780 and A2780CIS cells were treated with increasing concentrations of cisplatin. Cell vitality was assessed by CellTiterBlue ${ }^{\circledast}$ assay (left axis), whereas apoptosis was assessed by Caspase 3/7 Glo ${ }^{\oplus}$ assay (right axis). Data are shown as mean \pm standard deviation of at least three individual experiments. b. A2780CIS cells were treated with increasing concentrations of SIM for $48 \mathrm{~h}$. Farnesylation of Ras, geranylgeranylation of Rap1a, and cleavage of poly (ADP-ribose) polymerase (CPARP) were assessed by western blotting. Glyceraldehyde3-phosphate dehydrogenase (GAPDH) was used as loading control. The figures show representative blots which were cropped from original images. Full-length blots are presented in Suppl. Fig. 8. Images were detected using GelCapture 7.0.18 software. Expression of SW was assessed by real-time-PCR. Data are shown as mean \pm SEM of at least three individual experiments. ${ }^{* *} p<0.01 ;{ }^{* * *} p<0.001$ vs. respective control $(0 \mu \mathrm{M})$.

Additional file 5: Suppl. Fig. 5. Uncropped Western Blots for Fig. 1 a. The figure shows all original uncropped blots. As some membranes were used to simultaneously detect Ras and cleaved PARP (after cutting), the pictures here also include the cleaved PARP original blots used for Fig. 2a to keep the originality. All original blots for GAPDH are also included. Representative cropped GAPDH images are shown in Fig. 1a.
Additional file 6: Suppl. Fig. 6. Uncropped Western Blots for Fig. 2a. The figure shows all original uncropped blots. As some membranes were used to simultaneously detect Ras and cleaved PARP (after cutting), the pictures here also include the Ras original blots used for Fig. 1a to keep the originality. All original blots for GAPDH are also included. Representative cropped GAPDH images are shown in Fig. 2a.

Additional file 7: Suppl. Fig. 7. Uncropped Western Blots for Supplementary Figure 3a.

Additional file 8: Suppl. Fig. 8. Uncropped Western Blots for Supplementary Figure 4b.

\section{Abbreviations}

ATO: Atorvastatin; BCL-2: B-cell lymphoma 2; cPARP: Cleaved PARP; DMSO: Dimethyl sulfoxide; ELISA: Enzyme-linked immunosorbent assay; FCS: Fetal calf serum; FPP: Farnesyl pyrophosphate; GAPDH: Glyceraldehyde 3-phosphate dehydrogenase; GGPP: Geranylgeranyl pyrophosphate; HMGC R: 3-hydroxy-3-methylglutaryl-CoA reductase; IL6: Interleukin 6; IL8: Interleukin 8; N-BP: Amino-bisphosphonates; PARP: Poly (ADP-ribose) polymerase; qRTPCR: Quantitative real-time polymerase chain reaction; ROSU: Rosuvastatin; RT: Room temperature; SDS: Sodium dodecyl sulfate; SDS-PAGE: SDS polyacrylamide gel electrophoresis; SEM: Standard error of the mean; SIM: Simvastatin; SW: Survivin; TAMs: Tumor-associated macrophages; TBST: Tris-buffered saline with 1\% Tween-20; TGF 31 : Transforming growth factor $\beta 1$; TNFA: Tumor necrosis factor a; VEGF: Vascular endothelial growth factor; ZOL: Zoledronic acid

\section{Acknowledgements}

The authors would like to thank Dorit Breining and Stephanie Wieneke for their excellent technical assistance and Ms. Theresa Reiche for her secretarial assistance.

\section{Authors' contributions}

Study Design: AG and TDR. Study conduct: AG and VMZ. Data collection: AG, SD, NJ and VMZ. Data analysis: AG, VMZ, SD, NJ, JDK, and TDR. Data interpretation: AG, VMZ, JDK, PW, and TDR. Drafting Manuscript: AG and VMZ. Revising manuscript content: AG, VMZ, SD, NJ, JDK, PW, and TDR. Approving final version of manuscript: AG, VMZ, SD, NJ, JDK, PW, and TDR. $A G$ and VMZ take responsibility for the integrity of the data analysis. All authors have read and approved the manuscript.

\section{Funding}

The conduction and analysis of the study was funded by the Deutsche Forschungsgemeinschaft to AG (GO 3055/1-1) and to TDR (RA 2151/4-1 and 5-1) as part of the DFG Schwerpunktprogramm-2084 $\mu$ Bone as well as by the Deutsche Krebshilfe to AG and TDR (\#70113573 and as part of the Mildred-Scheel Nachwuchszentrum). Open access funding provided by Projekt DEAL.

\section{Availability of data and materials}

The datasets used and/or analyzed during the current study are available from the corresponding author on reasonable request.

\section{Ethics approval and consent to participate}

None of the used cell lines required ethics approval for their use.

\section{Consent for publication}

Not applicable.

\section{Competing interests}

The authors have received grants or honorarium for advisory boards or lectures to the individual or the institution by Amgen (PW, TDR), AstraZeneca $(P W)$, Novartis (PW, TDR), Pfizer (PW), Roche (PW), Tesaro (PW), PharmaMar (PW), TEVA (PW), and Merck (PW, TDR). AG, VMZ, SD, NJ, and JDK declare no conflict of interest.

\section{Author details}

'Division of Endocrinology, Diabetes, and Bone Diseases, Department of Medicine III, Technische Universität, Fetscherstraße 74, 01307 Dresden, Germany. ${ }^{2}$ German Cancer Consortium (DKTK), Partner Site Dresden and German Cancer Research Center (DKFZ), Heidelberg, Germany. ${ }^{3}$ Institute for 
Research in Biomedicine (IRB Barcelona), Barcelona Institute of Science and Technology, Barcelona, Spain. ${ }^{4}$ Center for Healthy Aging, Technische Universität Dresden, Dresden, Germany. ${ }^{5}$ Department of Internal Medicine I, Gastroenterology, Hepatology, Endocrinology and Metabolism, Medical University of Innsbruck, Innsbruck, Austria. ${ }^{6}$ Department of Gynecology and Obstetrics, Medical Faculty and University Hospital Carl Gustav Carus, Technische Universität Dresden, Dresden, Germany. ${ }^{7}$ National Center for Tumor Diseases (NCT), Dresden, Germany: German Cancer Research Center (DKFZ), Heidelberg, Germany; Faculty of Medicine and University Hospital Carl Gustav Carus, Technische Universität Dresden, Dresden, Germany; Helmholtz-Zentrum Dresden - Rossendorf (HZDR), Dresden, Germany.

\section{Received: 14 April 2020 Accepted: 10 July 2020}

\section{Published online: 29 July 2020}

\section{References}

1. Abubaker K, Latifi A, Luwor R, Nazaretian S, Zhu H, Quinn MA, et al. Shortterm single treatment of chemotherapy results in the enrichment of ovarian cancer stem cell-like cells leading to an increased tumor burden. Mol Cancer. 2013;12:24

2. Mor G, Visintin I, Lai Y, Zhao H, Schwartz P, Rutherford T, et al. Serum protein markers for early detection of ovarian cancer 2005;102:7677-82. https://doi.org/10.1073/pnas.0502178102.

3. Longuespée $\mathrm{R}$, Boyon $\mathrm{C}$, Desmons $\mathrm{A}$, Vinatier $\mathrm{D}$, Leblanc $\mathrm{E}$, Farré I, et al. Ovarian cancer molecular pathology. Cancer Metastasis Rev. 2012;31:713-32.

4. Ahmed N, Stenvers KL. Getting to know ovarian Cancer ascites: opportunities for targeted therapy-based translational research. Front Oncol. 2013;3:256.

5. Goff BA, Mandel L, Muntz HG, Melancon CH. Ovarian carcinoma diagnosis. Cancer. 2000:89:2068-75.

6. Bast RCJ, Hennessy B, Mills GB. The biology of ovarian cancer: new opportunities for translation. Nat Rev Cancer. 2009;9:415-28.

7. Nagy JA, Masse EM, Herzberg KT, Meyers MS, Yeo K, Yeo T. Pathogenesis of Ascites Tumor Growth: Vascular Permeability Factor, Vascular Hyperpermeability, and Ascites Fluid Accumulation. Cancer Res. 1995;55(2):360-8.

8. Kipps E, Tan DSP, Kaye SB. Meeting the challenge of ascites in ovarian cancer: new avenues for therapy and research. Nat Rev Cancer. 2013;13:273-82.

9. Herr D, Sallmann A, Bekes I, Konrad R, Holzheu I, Kreienberg R, et al. VEGF induces ascites in ovarian cancer patients via increasing peritoneal permeability by downregulation of Claudin 5. Gynecol Oncol. 2012;127:210-6.

10. Hennessy BT, Coleman RL, Markman M. Ovarian cancer. Lancet. 2009;374: 1371-82.

11. Jelovac D, Armstrong DKD. Recent progress in the diagnosis and treatment of ovarian cancer. CA Cancer J Clin. 2011;61:183-203.

12. Kampan NC, Madondo MT, MCNally OM, Quinn M, Plebanski M. Paclitaxel and its evolving role in the management of ovarian cancer. Biomed Res Int. 2015;2015:1-21.

13. Marchetti C, Muzii L, Romito A, Panici PB. First-line treatment of women with advanced ovarian cancer: focus on bevacizumab. Onco Targets Ther. 2019:12:1095-103.

14. Burger RA, Brady F, Bookman M, Fleming G, Monk B, Huang H, et al. Incorporation of Bevacizumab in the Primary Treatment of Ovarian Cancer. N Engl J Med. 2011:2473-83.

15. Perren T, Swart A, Pfisterer J, Ledermann J, Pujade-Lauraine E, Kristensen G, et al. A phase 3 trial of bevacizumab in ovarian cancer. N Engl J Med. 2011; 365:2484-96.

16. Gupta S, Nag S, Aggarwal S, Rauthan A, Warrier N. Maintenance therapy for recurrent epithelial ovarian cancer: current therapies and future perspectives - a review. J Ovarian Res. 2019:12:1-15.

17. Moore K, Colombo N, Scambia G, Kim BG, Oaknin A, Friedlander M, et al. Maintenance olaparib in patients with newly diagnosed advanced ovarian cancer. N Engl J Med. 2018;379:2495-505.

18. Ledermann J, Harter P, Gourley C, Friedlander M, Vergote I, Rustin G, et al. Olaparib maintenance therapy in patients with platinum-sensitive relapsed serous ovarian cancer: a preplanned retrospective analysis of outcomes by BRCA status in a randomised phase 2 trial. Lancet Oncol. 2014;15:852-61.

19. Pujade-Lauraine E, Ledermann JA, Selle F, Gebski V, Penson RT, Oza AM, et al. Olaparib tablets as maintenance therapy in patients with platinum sensitive, relapsed ovarian cancer and a BRCA1/2 mutation (SOLO2/ENGOTOv21): a double-blind, randomised, placebo-controlled, phase 3 trial. Lancet Oncol. 2017;18:1274-84.
20. Mirza MR, Monk BJ, Herrstedt J, Oza AM, Mahner S, Redondo A, et al. Niraparib maintenance therapy in platinum-sensitive, recurrent ovarian cancer. N Engl J Med. 2016;375:2154-64.

21. Coleman RL, Oza AM, Lorusso D, Aghajanian C, Oaknin A, Dean A, et al. Rucaparib maintenance treatment for recurrent ovarian carcinoma after response to platinum therapy (ARIEL3): a randomised, double-blind, placebocontrolled, phase 3 trial. Lancet (London, England). 2017;390:1949-61.

22. Markman M, Bookman MA. Second-line treatment of ovarian Cancer. Oncologist. 2000;5:26-35.

23. Markman M, Markman J, Webster K, Zanotti K, Kulp B. Duration of response to second-line, platinum-based chemotherapy for ovarian cancer: implications for patient management and clinical trial design. J Clin Oncol. 2004;22:3120-5.

24. Buhaescu I, Izzedine H. Mevalonate pathway: a review of clinical and therapeutical implications. Clin Biochem. 2007;40:575-84.

25. Göbel A, Rauner M, Hofbauer LC, Rachner TD. Cholesterol and beyond - the role of the mevalonate pathway in cancer biology. Biochim Biophys Acta Rev Cancer. 1873;2020:188351.

26. Thurnher M, Gruenbacher G, Nussbaumer O. Regulation of mevalonate metabolism in cancer and immune cells. Biochim Biophys Acta Mol Cell Biol Lipids. 1831;2013:1009-15.

27. McTaggart SJ. Isoprenylated proteins. Cell Mol Life Sci. 2006;63:255-67.

28. Sahai E, Marshall CJ. RHO-GTPases and cancer. Nat Rev Cancer. 2002;2: 133-42.

29. De Wolf E, Abdullah MI, Jones SM, Menezes K, Moss DM, Drijfhout FP, et al. Dietary geranylgeraniol can limit the activity of pitavastatin as a potential treatment for drug-resistant ovarian cancer. Sci Rep. 2017;7:1-10.

30. Brennan DJ, Brändstedt J, Rexhepaj E, Foley M, Pontén F, Uhlén M, et al. Tumour-specific HMG-COAR is an independent predictor of recurrence free survival in epithelial ovarian cancer. BMC Cancer. 2010;10:125.

31. Clendening JW, Pandyra A, Boutros PC, El Ghamrasni S, Khosravi F, Trentin $\mathrm{GA}$, et al. Dysregulation of the mevalonate pathway promotes transformation. Proc Natl Acad Sci U S A. 2010;107:15051-6.

32. Abate M, Laezza C, Pisanti S, Torelli G, Seneca V, Catapano G, et al. Deregulated expression and activity of Farnesyl Diphosphate synthase (FDPS) in Glioblastoma. Sci Rep. 2017;7:1-10.

33. Tania M, Khan MA, Song Y. Association of lipid metabolism with ovarian cancer. Curr Oncol. 2010;17:6-11.

34. Nelson ER, Wardell SE, Jasper JS, Park S, Suchindran S, Howe MK, et al. 27Hydroxycholesterol links hypercholesterolemia and breast cancer pathophysiology. Science. 2013;342:1094-8.

35. He S, Ma L, Baek AE, Vardanyan A, Vembar V, Chen JJ, et al. Host CYP27A1 expression is essential for ovarian cancer progression. Endocr Relat Cancer. 2019:26:659-75.

36. Mokady D, Meiri D. RhoGTPases - a novel link between cytoskeleton organization and cisplatin resistance. Drug Resist Updat. 2015;19:22-32.

37. Porter AP, Papaioannou A, Malliri A. Deregulation of rho GTPases in cancer. Small GTPases. 2016;7:123-38.

38. Goldstein JL, Brown MS. A century of cholesterol and coronaries: from plaques to genes to statins. Cell. 2015;161:161-72.

39. Demierre M-F, Demierre M-F, Higgins PDR, Higgins PDR, Gruber SB, Gruber SB, et al. Statins and cancer prevention. Nat Rev Cancer. 2005;5:930-42.

40. Liao JK, Laufs U. Pleiotropic effects of statins. Annu Rev Pharmacol Toxicol. 2005:45:89-118.

41. Gronich N, Rennert G. Beyond aspirin-cancer prevention with statins, metformin and bisphosphonates. Nat Rev Clin Oncol. 2013;10:625-42.

42. Clézardin P. Mechanisms of action of bisphosphonates in oncology: a scientific concept evolving from antiresorptive to anticancer activities. Bonekey Rep. 2013;2:267.

43. Wong WWL, Dimitroulakos J, Minden MD, Penn LZ. HMG-CoA reductase inhibitors and the malignant cell: the statin family of drugs as triggers of tumor-specific apoptosis. Leukemia. 2002;16:508-19.

44. Gnant M, Clézardin P. Direct and indirect anticancer activity of bisphosphonates: a brief review of published literature. Cancer Treat Rev. 2012:38:407-15.

45. Melani C, Sangaletti S, Barazzetta FM, Werb Z, Colombo MP. Aminobiphosphonate-mediated MMP-9 inhibition breaks the tumor-bone marrow axis responsible for myeloid-derived suppressor cell expansion and macrophage infiltration in tumor stroma. Cancer Res. 2007:67:11438-46.

46. Hiraga T, Williams PJ, Ueda A, Tamura D, Yoneda T. Zoledronic acid inhibits visceral metastases in the 4T1/luc mouse breast cancer model. Clin Cancer Res. 2004;10:4559-67. 
47. Bénard J, Da Silva J, De Blois MC, Boyer P, Riou G, Duvillard P, et al. Characterization of a human ovarian adenocarcinoma line, IGROV1, in tissue culture and in nude mice. Cancer Res. 1985;45:4970-9.

48. Behrens BC, Hamilton TC, Masuda H, Grotzinger KR, Whang-Peng J, Louie $K G$, et al. Characterization of a cis-diamminedichloroplatinum(II)-resistant human ovarian cancer cell line and its use in evaluation of platinum analogues. Cancer Res. 1987;47:414-8.

49. Berndt N, Sebti SM. Measurement of protein farnesylation and geranylgeranylation in vitro, in cultured cells and in biopsies, and the effects of prenyl transferase inhibitors. Nat Protoc. 2011;6:1775-91.

50. Franken NAP, Rodermond HM, Stap J, Haveman J, van Bree C. Clonogenic assay of cells in vitro. Nat Protoc. 2006;1:2315-9.

51. Göbel A, Thiele S, Browne AJ, Rauner M, Zinna VM, Hofbauer LC, et al. Combined inhibition of the mevalonate pathway with statins and zoledronic acid potentiates their anti-tumor effects in human breast cancer cells. Cancer Lett. 2016:375:162-71.

52. Göbel A, Breining D, Rauner M, Hofbauer LC, Rachner TD. Induction of 3 hydroxy-3-methylglutaryl-CoA reductase mediates statin resistance in breast cancer cells. Cell Death Dis. 2019;10:1-12.

53. Matte I, Lane D, Laplante C, Rancourt C, Piché A. Profiling of cytokines in human epithelial ovarian cancer ascites. Am J Cancer Res. 2012;2:566-80.

54. Kulbe H, Thompson R, Wilson $J$, Robinson S, Hagemann T, Fatah R, et al. The inflammatory cytokine tumor necrosis factor-a generates an autocrine tumor-promoting network in epithelial ovarian cancer cells. Cancer Res. 2007;67:585-92

55. Alsina-Sanchís E, Figueras A, Lahiguera A, Gil-Martín M, Pardo B, Piulats JM, et al. TGF $\beta$ controls ovarian cancer cell proliferation. Int J Mol Sci. 2017;18:1-10.

56. Kim A, Ueda Y, Naka T, Enomoto T. Therapeutic strategies in epithelial ovarian cancer. J Exp Clin Cancer Res. 2012;31:14.

57. Greenaway JB, Virtanen C, Osz K, Revay T, Hardy D, Shepherd T, et al. Ovarian tumour growth is characterized by mevalonate pathway gene signature in an orthotopic, syngeneic model of epithelial ovarian cancer. Oncotarget. 2016;7:47343-65

58. Couttenier A, Lacroix O, Vaes E, Cardwell CR, De Schutter H, Robert A. Statin use is associated with improved survival in ovarian cancer: a retrospective population-based study. PLoS One. 2017;12:1-14.

59. Lavie O, Pinchev M, Rennert HS, Segev Y, Rennert G. The effect of statins on risk and survival of gynecological malignancies. Gynecol Oncol. 2013;130:615-9.

60. Rennert G, Rennert HS, Pinchev M, Lavie O. The effect of bisphosphonates on the risk of endometrial and ovarian malignancies. Gynecol Oncol. 2014; 133:309-13.

61. Campbell MJ, Esserman LJ, Zhou Y, Shoemaker M, Lobo M, Borman E, et al. Breast cancer growth prevention by statins. Cancer Res. 2006;66:8707-14.

62. Karabulut B, Karaca B, Varol U, Muslu U, Cakar B, Atmaca H, et al. Enhancing cytotoxic and apoptotic effect in OVCAR-3 and MDAH-2774 cells with alltrans retinoic acid and zoledronic acid: a paradigm of synergistic molecular targeting treatment for ovarian cancer. J Exp Clin Cancer Res. 2010;29:102.

63. Kato S, Smalley S, Sadarangani A, Chen-Lin K, Oliva B, Brañes J, et al. Lipophilic but not hydrophilic statins selectively induce cell death in gynaecological cancers expressing high levels of HMGCoA reductase. J Cell Mol Med. 2010;14:1180-93.

64. Hashimoto K, Morishige K, Sawada K, Tahara M, Kawagishi R. Alendronate Inhibits Intraperitoneal Dissemination in In vivo Ovarian Cancer Model. Cancer Res. 2005;65:540-5.

65. Wolfe AR, Debeb BG, Lacerda L, Larson R, Bambhroliya A, Huang X, et al. Simvastatin prevents triple-negative breast cancer metastasis in pre-clinical models through regulation of FOXO3a. Breast Cancer Res Treat. 2015;154: 495-508.

66. Rachner TD, Singh SK, Schoppet M, Benad P, Bornhäuser M, Ellenrieder V, et al. Zoledronic acid induces apoptosis and changes the TRAIL/OPG ratio in breast cancer cells. Cancer Lett. 2010;287:109-16.

67. Goc A, Kochuparambil ST, Al-Husein B, Al-Azayzih A, Mohammad S, Somanath PR. Simultaneous modulation of the intrinsic and extrinsic pathways by simvastatin in mediating prostate cancer cell apoptosis. BMC Cancer. 2012;12:409.

68. Kochuparambil ST, Al-Husein B, Goc A, Soliman S, Somanath PR. Anticancer efficacy of simvastatin on prostate cancer cells and tumor xenografts is associated with inhibition of Akt and reduced prostate-specific antigen expression. J Pharmacol Exp Ther. 2011;336:496-505.

69. Oades GM, Senaratne SG, Clarke IA, Kirby RS, Colston KW. Nitrogen containing bisphosphonates induce apoptosis and inhibit the mevalonate pathway, impairing Ras membrane localization in prostate cancer cells. J Urol. 2003;170:246-52.

70. Tassone P, Tagliaferri P, Viscomi C, Palmieri C, Caraglia M, D'Alessandro A, et al. Zoledronic acid induces antiproliferative and apoptotic effects in human pancreatic cancer cells in vitro. Br J Cancer. 2003;88:1971-8.

71. Shipman CM, Rogers MJ, Apperley JF, Russell RGG, Croucher PI. Bisphosphonates induce apoptosis in human myeloma cell lines: a novel anti-tumour activity. Br J Haematol. 1997;98:665-72.

72. Yanae M, Tsubaki M, Satou T, Itoh T, Imano M, Yamazoe $Y$, et al. Statininduced apoptosis via the suppression of ERK1/2 and Akt activation by inhibition of the geranylgeranyl-pyrophosphate biosynthesis in glioblastoma. J Exp Clin Cancer Res. 2011;30:74.

73. Beckwitt CH, Shiraha K, Wells A. Lipophilic statins limit cancer cell growth and survival, via involvement of Akt signaling. PLoS One. 2018;13:1-22.

74. Robinson E, Nandi M, Wilkinson LL, Arrowsmith DM, Curtis ADM, Richardson A. Preclinical evaluation of statins as a treatment for ovarian cancer. Gynecol Oncol. 2013;129:417-24.

75. Liu H, Liang SL, Kumar S, Weyman CM, Liu W, Zhou A. Statins induce apoptosis in ovarian cancer cells through activation of JNK and enhancement of Bim expression. Cancer Chemother Pharmacol. 2009;63: 997-1005.

76. Raghu VK, Beckwitt CH, Warita K, Wells A. Biomarker identification for statin sensitivity of cancer cell lines. Biochem Biophys Res Commun. 2018;495: 659-65.

77. Abdullah MI, Abed MN, Richardson A. Inhibition of the mevalonate pathway augments the activity of pitavastatin against ovarian cancer cells. Sci Rep. 2017;7:1-13.

78. Domcke S, Sinha R, Levine DA, Sander C, Schultz N. Evaluating cell lines as tumour models by comparison of genomic profiles. Nat Commun. 2013;4:2126.

79. Clendening JW, Pandyra A, Li Z, Boutros PC, Martirosyan A, Lehner R, et al. Exploiting the mevalonate pathway to distinguish statin-sensitive multiple myeloma. Blood. 2010;115:4787-97.

80. Longo J, Mullen PJ, Yu R, van Leeuwen JE, Masoomian M, Woon DTS, et al. An actionable sterol-regulated feedback loop modulates statin sensitivity in prostate cancer. Mol Metab. 2019;25:119-30.

81. Casella C, Miller DH, Lynch K, Brodsky AS, Biology C. Oxysterols synergize with statins by inhibiting SREBP-2 in ovarian cancer cells. Gynecol Oncol. 2014;135:333-41.

82. Zheng L, Li L, Lu Y, Jiang F, Yang XA. SREBP2 contributes to cisplatin resistance in ovarian cancer cells. Exp Biol Med. 2018;243:655-62.

83. Sawada K, Morishige K i, Tahara M, Kawagishi R, Ikebuchi Y, Tasaka K, et al. Alendronate inhibits lysophosphatidic acid-induced migration of human ovarian cancer cells by attenuating the activation of Rho. Cancer Res. 2002; 62:6015-20

84. Green JR, Clézardin P. Mechanisms of bisphosphonate effects on osteoclasts, tumor cell growth, and metastasis. Am J Clin Oncol. 2002;25(6 Suppl 1):S3-9.

85. Fragni M, Bonini SA, Stabile A, Bodei S, Cristinelli L, Simeone C, et al. Inhibition of Survivin is associated with Zoledronic acid-induced apoptosis of prostate Cancer cells. Anticancer Res. 2016;36:913-20.

86. Chang HL, Chen CY, Hsu YF, Kuo WS, Ou G, Chiu PT, et al. Simvastatin induced HCT116 colorectal cancer cell apoptosis through p38MAPK-p53-survivin signaling cascade. Biochim Biophys Acta Gen Subj. 1830;2013:4053-64.

87. Åberg M, Wickström M, Siegbahn A. Simvastatin induces apoptosis in human breast cancer cells in a NFKB-dependent manner and abolishes the anti-apoptotic signaling of TF/FVlla and TF/FVIla/FXa. Thromb Res. 2008;122: 191-202.

88. Kar R, Sen S, Singh A, Sharma H, Kumar S, Gupta SD, et al. Role of apoptotic regulators in human epithelial ovarian cancer. Cancer Biol Ther. 2007;6: $1101-5$.

89. Cohen C, Lohmann CM, Cotsonis G, Lawson D, Santoianni R. Survivin expression in ovarian carcinoma: correlation with apoptotic markers and prognosis. Mod Pathol. 2003;16:574-83.

90. Wheatley SP, Altieri DC. Survivin at a glance. J Cell Sci. 2019;132:1-8.

91. Kassim SK, Ali HS, Sallam MM, Fayed ST, Seada LS, abd-Elkawy E, et al. Increased bcl-2 expression is associated with primary resistance to chemotherapy in human epithelial ovarian cancer. Clin Biochem. 1999;32: 333-8.

92. Mano Y, Kikuchi Y, Yamamoto K, Kita T, Hirata J, Tode T, et al. Bcl-2 as a predictor of chemosensitivity and prognosis in primary epithelial ovarian cancer. Eur J Cancer. 1999;35:1214-9. 
93. Galluzzi L, Senovilla L, Vitale I, Michels J, Martins I, Kepp O, et al. Molecular mechanisms of cisplatin resistance. Oncogene. 2012;31:1869-83.

94. Taylor-Harding B, Orsulic S, Karlan BY, Li AJ. Fluvastatin and cisplatin demonstrate synergistic cytotoxicity in epithelial ovarian cancer cells. Gynecol Oncol. 2010;1 19:549-56.

95. Kassim SK, El-Salahy EM, Fayed ST, Helal SA, Helal T, Azzam EED, et al. Vascular endothelial growth factor and interleukin-8 are associated with poor prognosis in epithelial ovarian cancer patients. Clin Biochem. 2004;37: 363-9.

96. Nilsson MB, Langley RR, Fidler IJ. Interleukin-6, secreted by human ovarian carcinoma cells, is a potent proangiogenic cytokine. Cancer Res. 2005;65: 10794-800.

97. Lane D, Matte I, Rancourt C, Piché A. Prognostic significance of IL-6 and IL-8 ascites levels in ovarian cancer patients. BMC Cancer. 2011;11:210.

98. Lamouille S, Xu J, Derynck R. Molecular mechanisms of epithelialmesenchymal transition. Natl Rev Mol Cell Biol. 2014;15:178-96.

99. Inan S, Vatansever S, Celik-Ozenci C, Sanci M, Dicle N, Demir R. Immunolocalizations of VEGF, its receptors flt-1, KDR and TGF-beta's in epithelial ovarian tumors. Histol Histopathol. 2006;21:1055-64.

100. Cai J, Tang H, Xu L, Wang X, Yang C, Ruan S, et al. Fibroblasts in omentum activated by tumor cells promote ovarian cancer growth, adhesion and invasiveness. Carcinogenesis. 2012:33:20-9.

101. Tran J, Master Z, Yu JL, Rak J, Dumont DJ, Kerbel RS. A role for survivin in chemoresistance of endothelial cells mediated by VEGF. Proc Natl Acad Sci U S A. 2002;99:4349-54.

102. Kumar J, Ward AC. Role of the interleukin 6 receptor family in epithelial ovarian cancer and its clinical implications. Biochim Biophys Acta Rev Cancer. 1845;2014:117-25.

103. Yin J, Zeng F, Wu N, Kang K, Yang Z, Yang H. Interleukin-8 promotes human ovarian cancer cell migration by epithelial-mesenchymal transition induction in vitro. Clin Transl Oncol. 2015;17:365-70.

104. Byrne AT, Ross L, Holash J, Nakanishi M, Hu L, Jaffe RB. Vascular Endothelial Growth Factor-Trap Decreases Tumor Burden, Inhibits Ascites, and Causes Dramatic Vascular Remodeling in an Ovarian Cancer Model. Clin Cancer Res. 2003:9:5721-8

105. Coward J, Kulbe H, Chakravarty P, Leader D, Vassileva V, Leinster DA, et al. UKPMC Funders Group Interleukin-6 as a therapeutic target in human ovarian cancer. 2012;17:6083-96. https://doi.org/10.1073/pnas.0502178102.

106. Duan S, Tsai Y, Keng P, Chen Y, Lee SO, Chen Y. IL-6 signaling contributes to cisplatin resistance in non-small cell lung cancer via the up-regulation of anti-apoptotic and DNA repair associated molecules. Oncotarget. 2015;6: 27651-60.

107. Stronach EA, Cunnea P, Turner C, Guney T, Aiyappa R, Jeyapalan S, et al. The role of interleukin-8 (IL-8) and IL-8 receptors in platinum response in high grade serous ovarian carcinoma. Oncotarget. 2015;6:31593-603.

108. Gazzerro P, Proto MC, Gangemi G, Malfitano AM, Ciaglia E, Pisanti S, et al. Pharmacological actions of statins: a critical appraisal in the management of cancer. Pharmacol Rev. 2012:64:102-46.

109. Chen T, Berenson J, Vescio R, Swift R, Gilchick A, Goodin S, et al. Pharmacokinetics and pharmacodynamics of zoledronic acid in cancer patients with bone metastases. J Clin Pharmacol. 2002;42:1228-36.

110. Hoffmann O, Schroer-Zuendorf IA, Kasimir-Bauer S, Oberhoff C, Kimmig R, Heubner M. Evaluation of the prognostic significance of disseminated tumor cells in the bone marrow of primary, non-metastatic breast cancer patients after a 7-year follow-up. Arch Gynecol Obstet. 2015;292:1117-25.

111. Hoffmann O, Aktas B, Goldnau C, Heubner M, Oberhoff C, Kimmig R, et al. Effect of ibandronate on disseminated tumor cells in the bone marrow of patients with primary breast cancer: a pilot study. Anticancer Res. 2011;31: $3623-8$

\section{Publisher's Note}

Springer Nature remains neutral with regard to jurisdictional claims in published maps and institutional affiliations.

Ready to submit your research? Choose BMC and benefit from:

- fast, convenient online submission

- thorough peer review by experienced researchers in your field

- rapid publication on acceptance

- support for research data, including large and complex data types

- gold Open Access which fosters wider collaboration and increased citations

- maximum visibility for your research: over $100 \mathrm{M}$ website views per year

At $\mathrm{BMC}$, research is always in progress.

Learn more biomedcentral.com/submissions 